\title{
Effect of Implementing an Educational program on Health Status Outcomes for Patients Congestive Heart Failure
}

\author{
Prof. Sanaa Mohammed Alaa El-Din; Prof. Ahmed El-Hawary, Assist Prof. Eman \\ Saleh Shahin, Sherin Ebrahim El-Tahry
}

Prof of Medical Surgical Nursing Department - Faculty of Nursing - Alexandria University; Prof and Head of Cardiology Department - Suez Canal University Faculty of Medicine; Assist Prof. of Medical Surgical Nursing - Faculty of Nursing Port Said University

\begin{abstract}
Background: The aim of this study is to evaluate the effect of implementing an educational program on health status outcome for patients congestive heart failure.

Subject and Methods: A quasi-experimental design was used to evaluate the effect of implementing an educational program on health status outcome for patients congestive heart failure. The subjects of the study was conducted in the cardiac care units in three selected governmental hospitals in Port Said city , El-Nasr Hospital, General Port Said Hospital and Al-Tadamon Health Insurance Hospital (The total sample size was 108 patients).Two tools was developed and used by the researcher for data collection. Tool: Congestive heart failure patients Questionnaire is divided into two parts. Part (1): This part included practice assessment regarding congestive heart failure and clinical data questionnaire as socio-demographic data and patient history and clinical data. Part (2): This part included educational program for patients with congestive heart failure. Results: After the educational program the results showed a positive statistically significant difference in the study group than control group in household activity(96.3\%), self-care(100\%), decrease load of work by others(62 .6\%)., sporting activity(72.2\%), take rest during work $(82.3 \%)$ and regular vacation(53.7\%), know hazards of smoking(98\%), not excessive salt and fat(13.0\% and 5.6\%) in the diet, and positive aspect of the life(72.2\%). , in the first second evaluation (after 3 months).Conclusion: Educational program has a significant improvement on health status outcome for patients congestive heart failure. Recommendation: education program for nurses working with CHF patient's concerning improve their information.
\end{abstract}

Key Words: Congestive heart failure, educational program and health status. 


\section{INTRODUCTION}

Congestive heart failure (CHF) occurs when the heart muscle is not able to pump enough blood to satisfy the metabolic needs of the tissues. Additionally, heart failure may be due to a primary disease of the heart muscle which is called cardiomyopathy or secondary to disease which affects the heart muscle such as hypertension, coronary heart disease, or various diseases of the heart valves (Amorim et al., 2013; Katz et al., 2015). CHF is often associated with disability and is characterized by left ventricular dysfunction, reduced exercise tolerance, diminished quality of life, and shortened life expectancy (McMurray et al., 2012). As indicated by Zill et al. (2011) a total of $50 \%$ of all patients with $\mathrm{CHF}$ die within 5 years of diagnosis.

Congestive heart failure is a complex clinical syndrome in which the patient complains of shortness of breath, fatigue and abnormal heart function. Heart failure is not a diagnosis but it is produced by any disorder that places the heart under a chronically increased volume or pressure load that produces primary damage or an increased metabolic demand on the myocardium (Pinkerman et al., 2013).

Furthermore, congestive heart failure is a significant health problem for men and women. It is characterized by marked functional limitation and poor quality of life, so the patients find themselves in a new life situation in their environment, their family, work and society. They usually face many problems such as loss of some body functions, relationships with others, altered sexuality and change in life style (Walker et al., 2014).

Moser et al. (2012) mentioned that patients with congestive heart failure need to have information regarding their own self-care. This information should include all aspects of their illness and its treatment. Moreover, Weber \& Kelley (2014), indicated that global information needs of patient with congestive heart failure help patient achieve high level of wellness. Moreover, the information that patients need to receive should be related to symptoms, medications, weight monitoring, diet, oxygen therapy, activity and stress management.....etc.

Patient with congestive heart failure should be prepared for transition of care from hospital to home through discharge planning. An effective discharge planning process 
could be described as the construction for implementation of a planned program of continuing care, which meets patients' needs after discharge from hospital (Urden et al., 2014; Jensen, 2015). The practice nurse plays an important role for patients with CHF. Which assesses patients' information regarding his/her disease to modify treatment and guide the patients and their families to facilitate adaptations with heart failure (Williams \& Hopper, 2015).

\section{SIGNIFICANCE OF THE STUDY:}

Congestive heart failure is considered as one of the most widely prevalent Egyptian health problems. Beside the dramatic influence of chronic heart disease on biopsychosocial conditions of patients and their families, it may present a challenge for health care professionals. Also most patients with congestive heart failure in Port Said city reported that mild to moderate impairment in functional status and partially dependent in self-care dimension, dependency in relation to mobility and impairment in psychosocial adaptation dimension (Eltahry 2008). Therefore that the patients' needs a more focused nursing care that manages all the related aspects that enhance patients' quality of life.

Congestive heart failure is a global term for the physiological state in which cardiac output is insufficient to meet the needs of the body and lung. Congestive heart failure is a major cause of chronic disability, and it is the leading cause of morbidity and mortality in most of the developed countries (Williams \& Hopper, 2015). Additionally, congestive heart failure is a complex syndrome and the most common reason for hospitalization and re hospitalization among older adults (Walker et al., 2014). There are many causes of CHF which vary in different parts of the world .The main causes for developing $\mathrm{CHF}$ are ischemic heart disease, hypertension, diabetes and coronary artery disease (Braun \& Anderson, 2011; McMurray et al., 2012).

The patients with CHF present difficult problems related to the disease and its treatment including chest pain, shortness of breath, tachycardia, fatigue and activity intolerance (Lakdizaji et al., 2013). Therefore, health care providers are constantly looking for factors that may predict patient outcomes, specifically hospitalization and death as a focus for new interventions (Bickiey \& Szilagyip, 2013).

Positive health outcomes for CHF patients depend on patient participation in the selection and use of appropriately focused heart failure self-care. Nurses and other caregivers usually observe and evaluate the patients need of information and self-care activities (Moser et al., 2012). On the other hand, patients should have accurate information about $\mathrm{CHF}$ and related symptoms, medication, weight monitoring, activity, rest/sleep, sexual problems and diet (Bickiey \& Szilagyip, 2013). 


\section{AIM OF STUDY:}

\section{Aim:}

This aim will be achieved through:

1.Assessing patients socio-demographic data.

2.Assessing health status in patients with CHF (pre, immediately, and 3 month post program).

3.Assessing patient's condition(pre, immediately, and 3 month post program).

4 . Develop educational program based on patients need .

5 .Assessment(theoretical \&practical)Implementing the program .

6.Evaluate the effectiveness of the program .

\section{SUBJECT AND METHODS:}

\section{Research design:}

A quasi-experimental design was used to evaluate the effect of implementing an educational program on health status outcome for patients congestive heart failure.

\section{Settings:}

The study was conducted in the cardiac care units in three selected governmental hospitals in Port Said city, El-Nasr Hospital, General Port Said Hospital and Al-Tadamon Health Insurance Hospital (The total sample size was 108 patients).

\section{Subjects of the study:}

Both study and control groups filled out the questionnaires through structured interview that consist of three assessment before implement program as a pre -test and immediate at the end of the program as post 1 then after three month as follow up test. then the educational program were conducted only for the study group according to their disease stage, level of education and their free time for most patient the teaching sessions were scheduled in the afternoon that consist of four session. Each session was done every week for one month and lasted for 30-45 minutes depending on certain circumstances such as patients level or depth of discussion.

\section{Subjects Selection:}

\section{Inclusion Criteria}

Patients above 40 years of age both sex males and females.

Patients with a confirmed diagnosis of congestive heart failure for at least one year.

\section{Exclusion Criteria:}

Patient inability to communicate due to poor general conditions and deafness hearing alteration. 


\section{TOOLS OF DATA COLLECTION:}

\section{Part (I) Practice Assessment Regarding Congestive Heart Failure and Clinical Data Questionnaire:}

This questionnaire was developed by the researcher after a thorough review of literature, this tool is divided into two main parts.

- Socio-demographic data: such as age, gender, marital status, level of education, job type, caregiver, home as location, number of children, family members living with the patient, number of rooms, crowding index, monthly income sufficient for costs of treatment.

- Patient history and clinical data: such as types, diagnosis of CHF, onset of illness, time since start (years), concomitant disease, number of hospitals admission in the last year, signs and symptoms as, edema , complications that occurred , smoking, exercise, laboratory investigations, vital signs, control of weight, diet, medication ,and sexual relation, (Abu Donia, 1977).

\section{Scoring System:}

Knowledge: For the knowledge items, a correct response was scored 1 and the incorrect scored zero. For each area of knowledge, the scores of the items were summed-up and the total divided by the number of items, giving a mean score for the part. These scores were converted into a percent score, and means and standard deviations were computed. Knowledge was considered satisfactory if the percent score was $60 \%$ or more and unsatisfactory if less than $60 \%$.

Performance: The items "not done" and "done" were scored " 0 " and "1", respectively. For each part, the scores of the items were summed-up and the total divided by the number of the items, giving a mean score for the part. These scores were converted into a percent score, and means and standard deviations were computed. The performance was considered adequate if the percent score was $60 \%$ or more, and inadequate if less than $60 \%$.

\section{Educational Program:}

The health education program was designed based on; several literature review and the findings of the baseline assessment of CHF patients' practice. The general objectives distributed on four sessions with each session having a set of specific objectives:

- The first session's aim was to: inform CHF patients about the anatomy and physiology of the heart, definition of CHF, risk factors, signs and symptoms

- The second session's aim was to: Instruction as regard medication to their therapeutic effect, dosage, routs of administration and side effects, management and control of possible complications, control of hypertension, oxygen therapy and cassation of smoking.

- The third session's aim was to: Personal exercise to improve quality of life. Instruction about weight reduction, serum lipids and salt reduction and nutrition control. 
- The fourth session's aim was to: teach CHF patients how to limitation of physical activity, decrease sleep disturbance, manage sexual relation problems, cope with stress management and medical checkup or follow up.

\section{Field work:}

The program contents and the choice of teaching methods were based on level of education and needs whether individually or in groups. An educational booklet, brochures and videos on copy-right disk $\mathrm{CD}$ were prepared by the researcher to present information for patients in a simple way using simple language and illustrative pictures. It distributed to all patients at the proper time.

\section{A pilot study:}

A pilot study was carried out on $10 \%$ of the patients. The main purpose of the pilot study was to test the clarity, feasibility of the tools and whether it was understandable, and to determine the time needed to fill the tool. The tool was handed to participants to fill it in and collected by the researcher.

Field study was conducted from the beginning of June (2013) to the end of August (2014). Reliability was performed for the tool where Cronbach alpha equals 0.751.

Conceptual definition: Health status defends as a holistic concept that is determined by more than the presence or absence of any disease. It is often summarized by life expectancy or self-assessed health status, and more broadly includes measures of functioning, physical illness, and mental wellbeing (Australian Institute of Health and Welfare, 2016).

\section{Administrative Design:}

Permission was obtained to carry out the study, from the directors and the heads of medical wards in the governmental hospitals and health insurance hospital in Port Said City after explanation of the study purpose.

\section{Ethical Consideration:}

The aim of the study was explained to directors, physicians and staff nurses at the participating hospitals who are caring for patients with congestive heart failure .Patients verbal consent was obtained before asking them to participate in the study after explaining of the aim, and ensuring the confidentiality of the information collected.

\section{Protection of Human Rights:}

After obtaining the official permission to conduct the study patients were informed about the aim and nature of the study. It was emphasized that the participation is voluntary and confidential and anonymity of the subject will be assured through coding of data. 


\section{(IV) STATISTICAL DESIGN:}

Data entry and statistical analysis were done using SPSS 14.0 statistical software package. Data were presented using descriptive statistics in the form of frequencies and percentages for qualitative variables, and means and standard deviations for quantitative variables. Quantitative continuous data were compared the non-parametric MannWhitney and Kruskal-Wallis tests were for comparisons between two groups and more than two groups, respectively as normal distribution of the data could not be assumed. Categoral variables were compared using chi-square test. Whenever the expected values in one or more of the cells in a $2 \times 2$ tables was less than 5, Fisher exact test was used instead. In larger than $2 \times 2$ cross-tables, no test could be applied whenever the expected value in $10 \%$ or more of the cells was less than 5 . Pearson correlation analysis was used for assessment of the inter-relationships among quantitative variables, and Spearman rank correlation for ranked ones. To assess the relationship between scores of knowledge, skills and practice as dependent factors, on the one hand, and various quantitative factors, as independent factors, on the other hand, multiple stepwise backward regression analysis was used, and analysis of variance for the full regression models were done. Statistical significance was considered at $\mathrm{p}$-value $<0.05$.

\section{RESULTS:}

Table (1): shows the distribution of socio-demographic characteristics of both study and control groups. None of the characteristics showed significant difference between both groups except type of work practiced by both groups $(p=0.001)$, gender $(p=0.053)$ and carer of family members $(\mathrm{P}=0.029)$.

Table (2): shows the Comparison between study and control groups as regards socioeconomic conditions. Differences in socio-economic conditions of both groups were statistically significantly between both groups. The floor of housing in about half of the study group was at the ground level $(40.7 \%)$ compared to the majority of the control group $(79.6 \%)$ who lived in the second floor $(\mathrm{P}=0.001)$. Healthy home was available for half of the study group (50\%) compared to the majority of the control group $(85.2 \%)$; $(\mathrm{P}=0.001)$. Monthly income was significantly lower among the control group $(\mathrm{P}=0.001)$. The majority of the control group (85.2\%) had income less than 300 LE compared to $64.8 \%$ of the study group who had income between 301 and 500 LE. Thus the majority of the control group (87\%) had insufficient income compared to $(51.9 \%)$ of the study group $(\mathrm{P}=0.001)$. Health insurance was offered for $(61.1 \%)$ of the study group compared to only $(14.8 \%)$ of the control group. The differences were statistically significant $(\mathrm{P}=0.001)$.

Table (3): reveals the distribution of knowledge about history of the disease among both studied patient and control groups. Knowledge about diagnosis was more encountered among the control group as compared to the study group $(\mathrm{P}=0.001)$. Knowledge about heart failure was more evident among study group as compared to the control group 
$(\mathrm{P}=0.001)$. Moreover, causes of heart failure were known to $(37 \%)$ of the study group compared to $(14.8 \%)$ of the control group $(\mathrm{P}=0.008)$.

Table (4): shows the medical history of diseases among the studied patient and control groups. All studied and control patient suffered from hypertension. The majority of the control group suffered from myocardial infarction (77.8\%) compared to (46.3\%) among patient followed by angina pectoris $(75.9 \%, 37 \%$ respectively) and severe anemia (66.7\%, 20.4\% respectively). All these differences were statistically significant. Meanwhile, valvular stenosis and bronchial asthma were significantly higher among studied patients $(13 \%, 24.1 \%)$ than controls $(0 \%, 9.3 \%)$. No significant differences were observed between both groups regarding diabetes mellitus, rheumatic heart disease, and hyperthyroidism.

Regarding onset of disease, the majority of studied- patient, had gradual onset of disease compared to all controls. The difference was statistically significant $(\mathrm{p}=0.003)$. The mean number of hospital admissions of both studied and control patient did not show significant difference $(6.1 \pm 5.6,5.9 \pm 5.2$ respectively), $(\mathrm{P}=0.85)$. Less than half of the subjects $(40.7 \%)$ were admitted for 1 week in hospital compared to $13 \%$ among the controls. Meanwhile, the majority of the controls $(72.2 \%)$ were admitted for 2 weeks compared to $25.9 \%$ among studied patient. Only $7.4 \%$ of patient and $3.7 \%$ of controls were admitted for more than 1 month. The differences were statistically significant $(\mathrm{p}=0.001)$. Cause for admission was almost heart failure combined with other causes among studied patient (75.9\%) and controls (66.7\%). The difference was statistically significant $(\mathrm{p}=0.001)$. More than half of studied patient $(57.4 \%)$ and controls $(53.7 \%)$ used to visit the physician at the same week of illness. No statistically significant difference was observed between both groups $(\mathrm{p}=0.1)$.

Considering knowledge about avoiding symptoms, it was only available among $22.2 \%$ of studied patient and $13 \%$ of controls. Nearly similar percentages were found among those who did not have the knowledge (31.5\%, 37\% respectively).

Table (5): shows the daily life activities among the studied patient and their controls. Regarding household activities, change observed among study group was increased as the percentage of those who reported "yes" increased from $(68.6 \%)$ before program to $(88.9 \%)$ and $(96.3 \%)$ after the program compared to $(20.4 \%$ and $37 \%)$ among control group. Differences observed between study and control group at different timings of evaluation were statistically significant. Rest periods between activities were studied. It was found that $(100 \%)$ of the studied patient who needed rest period between activities before program was (100\%) the percentage was then reduced to $92.6 \%$ after program in second evaluations. In comparison, the control group reported a constant percentage before and after conducting the program, which was (61.1\%).

Regarding self-care, the study group who reported "yes" constituted $94.5 \%$ before the program $100 \%$ after program at the $1^{\text {st }}$ and second evaluations. In comparison, the control group remained constant $(51.9 \%)$ at all evaluations. Differences between study 
and control groups were statistically significant. While, differences in the control group were not significant $(\mathrm{P}=0.976)$. Regarding regular vacations, the study group reported "yes" among (50\%) before program then it increased to $(55.6 \%$ and $53.7 \%)$ after the program. On the other hand, the control group who stated "yes" constituted $13 \%$ at all evaluations. Differences whereas study and control groups were statistically significant ( $\mathrm{P}=0.001$ ), whereas differences in between study group and within control group were not significant $(\mathrm{P}=1.0)$.

Considering sports activities, the study group did not practice sports before program which increased to $(72.2 \%)$ at $1^{\text {st }}$ and second evaluations after program. Meanwhile, control group did not practice sports before and after program. Differences were significant among study and controls. While, differences within study and controls separately were not significant.

Hobbies and entertainment were studied among both groups. Practicing hobbies increased among both study and control groups all observed differences in between both groups and within group were not statistically significant. Regarding if the disease affects work of studied subjects in both groups it was found that response in "yes" decreased at second evaluation of program among study group while it was constant in the control group.

Receiving rest during the work was increased after program among study group while only slight increase was observed among the control group. Differences between study and control groups were statistically significant $(\mathrm{P}=0.001)$ so as differences inside the study group $(\mathrm{P}=0.473)$. Meanwhile, differences among control group were not significant $(\mathrm{P}=0.973)$. No statistically significant differences was found in joining additional work among study group only it increased at $1^{\text {st }}$ evaluation after program from $5.9 \%$ to $13.7 \%$. All control group did not have additional work either before or after program. Percentage of study group subject who agreed that work load is decreased by others decreased after the program compared to none of the control group at all timing of evaluation. Differences between study and control groups were significant $(\mathrm{P}=0.001)$.On the contrary, differences within each group separately were not significant. Moreover, percentage of study group who agreed that they can increase work after the program. Again, differences between study and control groups were significant so as differences within the control group $(\mathrm{P}=0.873)$ but not significant among the study group $(\mathrm{P}=0.457)$.

Table (6): shows the effect of the educational program on diet and weight. Regarding place of having meals, it was revealed that study group who used to eat at home increased after program but no significant difference was found $(\mathrm{p}=0.15)$. Among control group, a lower percentage had meals at home and more or less, it was not changed after program. Thus, differences between control group so as those between study and control groups were not statistically significant. Considering person who choose the meal, the majority of both study and control groups reported that the "wife" 
is the person who chooses their meals. Differences between study and control groups were statistically significant while differences within each group before and after program were not significant. Number of daily meals was significantly different between study and control groups at all timings, study groups who consumed three meals daily increased after program $(\mathrm{P}=0.001)$ while they decreased significantly among control group $(\mathrm{P}=0.003)$. Subjects of the study group who preferred to eat large infrequent meals increased significantly after the program $(\mathrm{P}=0.001)$. On the other hand, control group did not show difference after the program as the majority of them preferred to have small infrequent meals. Differences between study and control groups were statistically significant at all timings $(\mathrm{P}=0.001)$.

Use of excessive salt was reported among (40.7\%) of the study group before the program then it was reduced to be $(0 \%)$ of the study group after the program. Percentage of control group who used excessive salt was constant before and after program $(33.3 \%)$. Differences in between each group were not significant so as differences between study and control groups before the program. Differences between both group after the program were statistically significant.

Regarding use of excessive fat in food, the study group subjects who did not use excessive fat increased from before program $(68.5 \%)$ to after program $(83.3 \%$ and $94.4 \%$ respectively). Still, differences were not statistically significant. Control group subjects who reported that they did not use excessive fat in food were significantly lower than those of study group at all timings $(\mathrm{P}=0.001)$. Again, no change was reported before and after the program among the control group $(\mathrm{P}=0.97)$.

Use of easy digestible food was decreased among the study group from (94.5\%) before program to $(87.1 \%)$ and $(92.6 \%)$ after the program. Differences observed were not statistically significant $(\mathrm{P}=0.362)$. On the other hand, $(61.1 \%)$ of control group agreed that they used digestible food before program which was not increased on further evaluation. Differences were not significant $(\mathrm{P}=0.975)$. Meanwhile, differences between study and control groups were statistically significant at all timings of evaluation $(\mathrm{P}=0.001)$.

Eating unhealthy food decreased among the study group on evaluations after program. Differences in each group were statistically significant $(\mathrm{P}=0.001)$. Eating unhealthy foods significantly differ between study and control groups before the program $(\mathrm{P}=0.001)$. Then, a significant reduction in eating unhealthy food was noticed among the study group. Thus, differences between the study and control groups were statistically significant $(\mathrm{P}=0.001)$. Following diet after discharge was significantly higher among study group than the control groups at all timings of the evaluation $(\mathrm{P}=0.001)$. Feeling that diet is a problem was more encountered among the study group as compared to the control group at all timings $(\mathrm{P}=0.001,0.001,0.011)$. Again, reduction of this feeling was significantly encountered among the study group after the program $(\mathrm{P}=0.021)$ but not 
among the control group $(\mathrm{P}=1$.0). Receiving medical knowledge about diet was reported by more half of both study and control groups before the program .It increase among the study group from (64.9\%) before program to (74.1\%) at 1st and 2nd evaluation .Differences observed were statistically significant $(\mathrm{P}=0.044)$. On other hand, (55.5\%) of control group in before and after program.

Control of weight was reported among a larger percentage of study group after the program. Differences were not statistically significant $(\mathrm{P}=0.025)$. Increased percentage of weight control among the control group was observed at 2nd evaluations after the program. Differences were not statistically significant $(\mathrm{P}=0.539)$. Differences between the study and control groups were significant at 1 st evaluation of the program $(\mathrm{P}=0.049)$ where as more control group reported control of their weight, differences between both groups were not significant $(\mathrm{P}=0.236)$.

Regular weight checking was not significantly encountered among the study group $(66.7 \%)$ as compared to the control group (52.1\%). Percentage of the study group who checked their weight regularly increased after 1st evaluation of the program thus differences within the group were not significant $(\mathrm{P}=0.971)$. Meanwhile, differences between the study and control group after the program so as differences within the control groups were not significant.

Table (7): reveals the effect of the educational program on use of medications among study and control group at three phases before, first and second evaluations. Regarding knowledge about medications and their dosage, it increased among the study group from (64 .8\%) before the program to $(88.9 \%$ and $90.8 \%)$ after the program. Differences were significant $(\mathrm{P}=0.01)$.

Meanwhile, no changes were detected among the control group at different evaluations $(\mathrm{P}=1.0)$. Knowledge among the study group was not significantly lower than that of control group (64.8\% and $85.2 \%$ respectively) $(\mathrm{P}=0.015)$. On the other hand, immediately after the program knowledge of study group (88 .9\%) was significantly higher than the control group $(85.2 \%),(\mathrm{P}=0.567)$. Then, no significant difference was observed at second evaluation after the program in control group as knowledge of the study group increased $(\mathrm{P}=0.375)$.

A higher percentage of the control group at all timings suffered from side effects of medications as compared to the study group. The percentage of those who suffered of side effects among the study group decreased after the program significantly $(\mathrm{P}=0.026)$. Taking an overdose of medication without consulting a physician was decreased among the study group from (42.6\% to 13\%) after the program. Similarly, only small reduction of that behavior was reported among the control group from 37.0 to $33.3 \%$ after the program. 
Differences within both groups were significant. Taking an overdose was more prevalent among the control rather than the study group at all timings of the evaluations. Differences were statistically significant.

Feeling depressed as a result for receiving medications for the whole life decreased among the study group from $(98.2 \%)$ before the program to $(90.7 \%)$ at the $1^{\text {st }}$ evaluation and $(96.3 \%)$ at $2^{\text {nd }}$ evaluation of the program. The control group showed the same $(100 \%)$ before and after the program. The control group showed higher percentage of depressed persons at all times. Differences were not significant.

Receiving health education about medication use by the health team was significantly higher among the study group rather than the control group. Moreover, percentage of subjects of the study group who reported that they had health education increased from (74.1\%) before the program to $(100 \%)$ at $1^{\text {st }}$ and $2^{\text {nd }}$ evaluation of the program. Differences were statistically significant $(\mathrm{P}=0.001)$. On the other hand, only a small percentage of the control group showed increased health education thus no significant difference was observed $(\mathrm{P}=0.902)$.

Table (8): describes the effect of the educational program on risky habits among the study and control groups. Regarding smoking habit, nearly equal percentage of smokers were found in both study (35.2\%) and control group (37.0\%). Thus, no significant difference was found between both groups before the program. After the program, no smokers were found among the study group while nearly no change was found among the control group. Differences between both groups were statistically significant at both timings of evaluation after the program $(\mathrm{P}=0.001)$. Knowledge about hazards of smoking increased among both groups after the program still nearly all the study groups (98\%) were knowledgeable about the hazards compared to $(57.1 \%)$ of the control group after the program. Differences between both groups at all timings were statistically significant $(\mathrm{P}=0.001)$. Having another family member who smokes was equal among both study and control groups representing (77.8\%).

Trials to quit smoking had been reported in a significantly higher percentage of the study group $(52.4 \%, 90.5 \%$ and $90.5 \%$ respectively) compared to $0 \%, 10 \%, 10 \%$ respectively) among the control group. All differences were statistically significant where $(\mathrm{P}=0.001)$.

None of both groups reported drinking alcohol before the program regularly. Meanwhile, after the program, only one subject of the study group reported regular alcohol consumption constituting (1.9\%). Differences between both groups were not significant $(\mathrm{P}=1.0)$.

A higher percentage of the study group knew the hazards of alcohol consumption; $(66.7 \%)$ before the program and $(87 . \%)$ after the 2 nd evaluation of the program) compared to $(87.1 \%)$ among the control group before the program and (100\%) after the 2nd evaluation. Differences were statistically significant $(\mathrm{P}=0.001)$. 
Table (1): Distribution of socio-demographic characteristics of the study and control group

\begin{tabular}{|c|c|c|c|c|}
\hline $\begin{array}{l}\text { Socio-demographic } \\
\text { characteristics }\end{array}$ & $\begin{array}{l}\text { Study } \\
\text { group } \\
(n=54)\end{array}$ & $\begin{array}{c}\text { Control } \\
\text { group } \\
(n=54)\end{array}$ & $\begin{array}{c}\text { Total } \\
(\mathbf{n}=108)\end{array}$ & $P$ value \\
\hline \multicolumn{5}{|l|}{ Gender } \\
\hline Male & $25(46.3 \%)$ & $35(64.8 \%)$ & $60(55.6 \%)$ & \multirow[t]{2}{*}{$0.053^{*}$} \\
\hline Female & $29(53.7 \%)$ & $1935.2 \%$ & $48(44.4 \%)$ & \\
\hline \multicolumn{4}{|l|}{ Age (years) } & \multirow{2}{*}{0.36} \\
\hline Mean \pm SD & $57.62 \pm 7.03$ & $56.24 \pm 8.58$ & $56.93 \pm 7.84$ & \\
\hline \multicolumn{4}{|l|}{ Social state } & \multirow{5}{*}{0.29} \\
\hline Single & $4(7.4 \%)$ & $6(11.1 \%)$ & $10(9.3 \%)$ & \\
\hline Married & $38(70.4 \%)$ & $33(61.1 \%)$ & $71(65.7 \%)$ & \\
\hline Widow & $12(22.2 \%$ & $12(22.2 \%)$ & $24(22.2 \%)$ & \\
\hline Divorced & $0(0.0 \%)$ & $3(5.6 \%)$ & $3(2.8 \%)$ & \\
\hline \multicolumn{4}{|l|}{ Educational level } & \multirow{5}{*}{0.065} \\
\hline Illiterate & $13(24.1 \%)$ & $19(35.2 \%)$ & $32(29.6 \%)$ & \\
\hline Read and write & $22(40.7 \%)$ & $25(46.3 \%)$ & $47(43.5 \%)$ & \\
\hline Prep school & $2(3.7 \%)$ & $4(7.4 \%)$ & $6(5.6 \%)$ & \\
\hline Secondary or above & $17(31.5 \%)$ & $6(11.1 \%)$ & $23(21.3 \%)$ & \\
\hline \multicolumn{4}{|l|}{ Employment } & \multirow{3}{*}{0.11} \\
\hline No & $23(42.6 \%)$ & $15(27.8 \%)$ & $38(35.2 \%)$ & \\
\hline Yes & $31(57.4 \%)$ & $39(72.2 \%)$ & $70(64.8 \%)$ & \\
\hline Type of work & $(n=31)$ & $(n=39)$ & $(n=70)$ & \multirow{3}{*}{$0.001 *$} \\
\hline Physical & $21(67.7 \%)$ & $38(97.4 \%)$ & $59(84.3 \%)$ & \\
\hline Mental & $10(32.3 \%)$ & $1(2.6 \%)$ & $11(15.7 \%)$ & \\
\hline \multicolumn{4}{|l|}{ Carer } & \multirow{5}{*}{$0.029 *$} \\
\hline Family & $32(59.3 \%)$ & $39(72.2 \%)$ & $71(65.7 \%)$ & \\
\hline One of sons & $13(24.1 \%)$ & $13(24.1 \%)$ & $26(24.1 \%)$ & \\
\hline Brother & $1(1.9 \%)$ & $2(3.7 \%)$ & $3(2.8 \%)$ & \\
\hline No one & $8(14.8 \%)$ & $0(0.0 \%)$ & $8(7.4 \%)$ & \\
\hline \multicolumn{4}{|l|}{ Residence } & \multirow{3}{*}{0.3} \\
\hline Special & $43(79.6 \%)$ & $47(87.0 \%)$ & $90(83.3 \%)$ & \\
\hline with others & $11(20.4 \%)$ & $7(13.0 \%)$ & $18(16.7 \%)$ & \\
\hline
\end{tabular}

*significant level considered- $P \leq 0.05$ 
Table (2): Comparison between study and control groups as regards socio-economic conditions

\begin{tabular}{|l|c|c|c|c|}
\hline \multicolumn{1}{|c|}{$\begin{array}{c}\text { Socio-economic } \\
\text { conditions }\end{array}$} & $\begin{array}{c}\text { Study group } \\
(\mathbf{n = 5 4 )}\end{array}$ & $\begin{array}{c}\text { Control } \\
\text { group } \\
(\mathbf{n = 5 4})\end{array}$ & $\begin{array}{c}\text { Total } \\
(\mathbf{n = 1 0 8})\end{array}$ & P value \\
\hline Floor of housing & $22(40.7 \%)$ & $7(13.0 \%)$ & $29(26.9 \%)$ & \\
At the ground & $6(11.1 \%)$ & $2(3.7 \%)$ & $8(7.4 \%)$ & $0.001^{*}$ \\
First & $17(31.5 \%)$ & $43(79.6 \%)$ & $60(55.6 \%)$ & \\
Second & $5(9.3 \%)$ & $0(0.0 \%)$ & $5(4.6 \%)$ & \\
Third & $4(7.4 \%)$ & $2(3.7 \%)$ & $6(5.6 \%)$ & \\
Others & $4(7.4 \%)$ & $2(3.7 \%)$ & $6(5.6 \%)$ & 0.4 \\
\hline Elevator & $50(92.6 \%)$ & $52(96.3 \%)$ & $102(94.4 \%)$ & \\
Present & $27(50.0 \%)$ & $46(85.2 \%)$ & $73(67.6 \%)$ & $0.001^{*}$ \\
Absent & $27(50.0 \%)$ & $8(14.8 \%)$ & $35(32.4 \%)$ & \\
\hline Healthy home & & & & \\
Yes & $17(31.5 \%)$ & $46(85.2 \%)$ & $63(58.3 \%)$ & $0.001^{*}$ \\
No & $35(64.8 \%)$ & $8(14.8 \%)$ & $43(39.8 \%)$ & \\
\hline Monthly income & $2(3.7 \%)$ & $0(0.0 \%)$ & $2(1.9 \%)$ & \\
Less than 300 & & & & \\
From 301-500 & $13(24.1 \%)$ & $7(13.0 \%)$ & $20(18.5 \%)$ & $0.001^{*}$ \\
More than 500 & $28(51.9 \%)$ & $47(87.0 \%)$ & $75(69.4 \%)$ & \\
\hline Sufficiency of income & $13(24.1 \%)$ & $0(0.0 \%)$ & $13(12.0 \%)$ & \\
Yes & & & & \\
No & $33(61.1 \%)$ & $8(14.8 \%)$ & $41(38.0 \%)$ & $0.001^{*}$ \\
Somewhat & $21(38.9 \%)$ & $46(85.2 \%)$ & $67(62.0 \%)$ & \\
\hline Health insurance & & & \\
Yes & & & & \\
No & & & & \\
\hline
\end{tabular}

*significant level considered- $P \leq 0.05$

Table (3): Knowledge about history of the disease in study and control groups

\begin{tabular}{|l|l|c|c|c|c|}
\hline \multicolumn{2}{|c|}{$\begin{array}{c}\text { Knowledge about disease } \\
\text { history }\end{array}$} & $\begin{array}{c}\text { Study } \\
\text { group } \\
(\mathbf{n = 5 4})\end{array}$ & $\begin{array}{c}\text { Control group } \\
(\mathbf{n = 5 4 )}\end{array}$ & $\begin{array}{c}\text { Total } \\
(\text { n=108) }\end{array}$ & P value \\
\hline $\begin{array}{l}\text { Know diagnosis } \\
\text { of the disease }\end{array}$ & Yes & $\begin{array}{l}40(74.1 \%) \\
14(25.9 \%)\end{array}$ & $\begin{array}{c}52(96.3 \%) \\
2(3.7 \%)\end{array}$ & $\begin{array}{c}92(85.2 \%) \\
16(14.8 \%)\end{array}$ & $0.001^{*}$ \\
\hline Know heart failure & Yes & $36(66.7 \%)$ & $16(29.6 \%)$ & $52(48.1 \%)$ & $0.001^{*}$ \\
\hline Cause of heart & No & $18(33.3 \%)$ & $38(70.4 \%)$ & $56(51.9 \%)$ & \\
failure & Yes & $20(37.0 \%)$ & $8(14.8 \%)$ & $28(25.9 \%)$ & $0.008^{*}$ \\
\hline Type of heart failure & No & $34(63.0 \%)$ & $46(85.2 \%)$ & $80(74.1 \%)$ & $0.004^{*}$ \\
\hline & Yos & $10(18.5 \%)$ & $1(1.9 \%)$ & $11(10.2 \%)$ & \\
\hline
\end{tabular}

*significant level considered- $\quad P \leq 0.05$ 
Table (4): Medical history of the disease among the study and control groups

\begin{tabular}{|c|c|c|c|c|c|}
\hline \multicolumn{2}{|c|}{ Medical history } & $\begin{array}{l}\text { Study } \\
\text { group } \\
(\mathrm{n}=54)\end{array}$ & $\begin{array}{l}\text { Control } \\
\text { group } \\
(\mathrm{n}=54)\end{array}$ & $\begin{array}{c}\text { Total } \\
(\mathbf{n}=\mathbf{1 0 8})\end{array}$ & $P$ value \\
\hline \multirow[t]{8}{*}{ Previous disease } & Hypertension & $54(100 \%)$ & $54(100 \%)$ & $108(100 \%)$ & - \\
\hline & MI & $25(46.3 \%)$ & $42(77.8 \%)$ & $67(62.0 \%)$ & $0.001^{*}$ \\
\hline & Rheumatic heart & $7(13.0 \%)$ & $2(3.7 \%)$ & $9(8.3 \%)$ & 0.08 \\
\hline & Angina pectoris & $20(37.0 \%)$ & $41(75.9 \%)$ & $61(56.5 \%)$ & $0.001 *$ \\
\hline & Valvular stenosis & $7(13.0 \%)$ & $0(0.0 \%)$ & $7(6.5 \%)$ & $0.019^{*}$ \\
\hline & Severe anemia & $11(20.4 \%)$ & $36(66.7 \%)$ & $47(43.5 \%)$ & $0.001 *$ \\
\hline & Hyperthyroidism & $4(7.4 \%)$ & $7(13.0 \%)$ & $11(10.2 \%)$ & 0.34 \\
\hline & Bronchial asthma & $13(24.1 \%)$ & $5(9.3 \%)$ & $18(16.7 \%)$ & $0.03 *$ \\
\hline \multirow[t]{2}{*}{ Diagnosis } & Sudden & $8(14.8 \%)$ & $0(0.0 \%)$ & $8(7.4 \%)$ & \multirow{2}{*}{$0.003^{*}$} \\
\hline & Gradual & $46(85.2 \%)$ & $54(100.0 \%)$ & $100(92.6 \%)$ & \\
\hline \multirow[t]{2}{*}{ Duration } & One year & $2(3.7 \%)$ & $0(0.0 \%)$ & $2(1.9 \%)$ & \multirow{2}{*}{0.15} \\
\hline & More than one year & $52(96.3 \%)$ & $54(100.0 \%)$ & $106(98.1 \%)$ & \\
\hline \multirow[t]{4}{*}{ Other diseases } & Diabetes & $2(3.7 \%)$ & $0(0.0 \%)$ & $2(1.9 \%)$ & \multirow{4}{*}{$0.021 *$} \\
\hline & Hypertension & $5(9.3 \%)$ & $0(0.0 \%)$ & $5(4.6 \%)$ & \\
\hline & DM and HTN & $46(85.2 \%)$ & $49(90.7 \%)$ & $95(88.0 \%)$ & \\
\hline & Others & $1(1.9 \%)$ & $5(9.3 \%)$ & $6(5.6 \%)$ & \\
\hline \multicolumn{2}{|c|}{ Admission in last year $($ mean \pm SD $)$} & $6.09 \pm 5.62$ & $5.90 \pm 5.19$ & $6.0 \pm 5.38$ & 0.85 \\
\hline \multirow{5}{*}{$\begin{array}{l}\text { Duration of } \\
\text { admission }\end{array}$} & One week & $22(40.7 \%)$ & $7(13.0 \%)$ & $29(26.9 \%)$ & \multirow{5}{*}{$0.001 *$} \\
\hline & Two weeks & $14(25.9 \%)$ & $39(72.2 \%)$ & $53(49.1 \%)$ & \\
\hline & Three weeks & $7(13.0 \%)$ & $1(1.9 \%)$ & $8(7.4 \%)$ & \\
\hline & One month & $7(13.0 \%)$ & $5(9.3 \%)$ & $12(11.1 \%)$ & \\
\hline & Others & $4(7.4 \%)$ & $2(3.7 \%)$ & $6(5.6 \%)$ & \\
\hline \multirow{3}{*}{$\begin{array}{l}\text { Cause of } \\
\text { admission }\end{array}$} & $\mathrm{HF}$ & $12(22.2 \%)$ & $0(0.0 \%)$ & $12(11.1 \%)$ & \multirow{3}{*}{$0.001 *$} \\
\hline & Others & $1(1.9 \%)$ & $18(33.3 \%)$ & $19(17.6 \%)$ & \\
\hline & HF and others & $41(75.9 \%)$ & $36(66.7 \%)$ & $77(71.3 \%)$ & \\
\hline \multirow[t]{4}{*}{ Visit doctor } & At the same week & $31(57.4 \%)$ & $29(53.7 \%)$ & $60(55.6 \%)$ & \multirow{4}{*}{0.10} \\
\hline & At the same month & $18(33.3 \%)$ & $25(46.3 \%)$ & $43(39.8 \%)$ & \\
\hline & After 3 months & $3(5.6 \%)$ & $0(0.0 \%)$ & $3(2.8 \%)$ & \\
\hline & After 6 months & $2(3.7 \%)$ & $0(0.0 \%)$ & $2(1.9 \%)$ & \\
\hline \multirow{3}{*}{$\begin{array}{l}\text { Know how to } \\
\text { avoid } \\
\text { symptoms }\end{array}$} & Yes & $12(22.2 \%)$ & $7(13.0 \%)$ & $19(17.6 \%)$ & \multirow{3}{*}{0.44} \\
\hline & No & $17(31.5 \%)$ & $20(37.0 \%)$ & $37(34.3 \%)$ & \\
\hline & Somewhat & $25(46.3 \%)$ & $27(50.0 \%)$ & $52(48.1 \%)$ & \\
\hline
\end{tabular}

N.B. No cases reported previous congenital heart disease or chronic chest disease *significant level considered- $P \leq 0.05$ 
Table (5): Effect of educational program on the daily life activities among study and control group at three phases: before, at first and 2nd evaluations.

\begin{tabular}{|c|c|c|c|c|c|c|c|c|c|c|c|c|c|c|c|}
\hline \multirow[b]{3}{*}{ Activities } & \multicolumn{5}{|c|}{ Before program } & \multicolumn{5}{|c|}{ At First evaluation } & \multicolumn{5}{|c|}{ At Second evaluation } \\
\hline & \multicolumn{2}{|c|}{$\begin{array}{c}\text { Study group } \\
(\mathrm{n}=54)\end{array}$} & \multicolumn{2}{|c|}{$\begin{array}{c}\text { Control group } \\
(\mathrm{n}=54)\end{array}$} & \multirow[t]{2}{*}{ Pvalue } & \multicolumn{2}{|c|}{$\begin{array}{c}\text { Study group } \\
(\mathrm{n}=54)\end{array}$} & \multicolumn{2}{|c|}{$\begin{array}{c}\text { Control group } \\
(\mathrm{n}=54)\end{array}$} & \multirow[t]{2}{*}{$\begin{array}{c}P \\
\text { value }\end{array}$} & \multicolumn{2}{|c|}{$\begin{array}{l}\text { Study group } \\
(\mathrm{n}=54)\end{array}$} & \multicolumn{2}{|c|}{$\begin{array}{c}\text { Control group } \\
(n=54)\end{array}$} & \multirow[t]{2}{*}{$\begin{array}{c}P \\
\text { value }\end{array}$} \\
\hline & No. & $\%$ & No. & $\%$ & & No. & $\%$ & No. & $\%$ & & No. & $\%$ & No. & $\%$ & \\
\hline \multicolumn{16}{|c|}{ Household activities } \\
\hline Yes & 37 & 68.6 & 11 & 20.4 & $0.001^{*}$ & 48 & 88.9 & 20 & 37 & $0.001^{*}$ & 52 & 96.3 & 20 & 37 & $0.001^{*}$ \\
\hline No & 17 & 31.5 & 43 & 79.6 & & 6 & 11.1 & 34 & 63 & & 2 & 3.7 & 34 & 63 & \\
\hline Sig. & \multicolumn{15}{|c|}{ Study group: $Z=17.12\left(P=0.001^{*}\right)$, control group: $Z=4.64(P=0.098)$} \\
\hline \multicolumn{16}{|c|}{ Religious activities } \\
\hline Yes & 52 & 96.3 & 54 & 100 & 0.495 & 54 & 100 & 54 & 100 & -NA- & 54 & 100 & 54 & 100 & -NA- \\
\hline No & 2 & 3.7 & 0 & 0 & & 0 & 0 & 0 & 0 & & 0 & 0 & 0 & 0 & \\
\hline Sig. & \multicolumn{15}{|c|}{ Study group: $Z=4.05(P=0.132)$, control group: $N A$} \\
\hline \multicolumn{16}{|c|}{ Rest periods between activities } \\
\hline Yes & 54 & 100 & 33 & 61.1 & $0.001^{*}$ & 54 & 100 & 33 & 61.1 & $0.001^{*}$ & 50 & 92.6 & 54 & 100 & 0.118 \\
\hline No & 0 & 0 & 21 & 38.9 & & 0 & 0 & 21 & 38.9 & & 4 & 7.4 & 0 & 0 & \\
\hline Sig. & \multicolumn{15}{|c|}{ Study group: $Z=35.29\left(P=0.001^{*}\right)$, control group: $Z=28.35\left(P=0.001^{*}\right)$} \\
\hline \multicolumn{16}{|l|}{ Self care } \\
\hline Yes & 51 & 94.5 & 27 & 50 & $0.001^{*}$ & 54 & 100 & 28 & 51.9 & $0.001^{*}$ & 54 & 100 & 28 & 51.9 & $0.001^{*}$ \\
\hline No & 3 & 5.6 & 27 & 50 & & 0 & 0 & 26 & 48.1 & & 0 & 0 & 26 & 48.1 & \\
\hline Sig. & \multicolumn{15}{|c|}{ Study group: $Z=6.11\left(P=0.047^{*}\right)$, control group: $Z=0.05(P=0.976)$} \\
\hline \multicolumn{16}{|c|}{ Regular vacations } \\
\hline Yes & 27 & 50 & 7 & 13 & $0.001^{*}$ & 30 & 55.6 & 7 & 13 & $0.001^{*}$ & 29 & 53.7 & 7 & 13 & $0.001^{*}$ \\
\hline No & 27 & 50 & 47 & 87 & & 24 & 44.4 & 47 & 87 & & 25 & 46.3 & 47 & 87 & \\
\hline Sig. & \multicolumn{15}{|c|}{ Study group: $Z=0.35(P=0.841)$, control group: $Z=0.001(P=1.0)$} \\
\hline \multicolumn{16}{|c|}{ 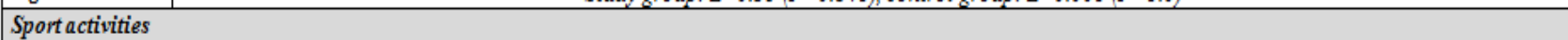 } \\
\hline Yes & 6 & 11.1 & 20 & 37 & $0.002^{*}$ & 39 & 72.2 & 21 & 38.9 & $0.001^{*}$ & 39 & 72.2 & 21 & 38.9 & $0.001^{*}$ \\
\hline No & 48 & 88.9 & 34 & 63 & & 15 & 27.8 & 33 & 61.1 & & 15 & 27.8 & 33 & 61.1 & \\
\hline Sig. & \multicolumn{15}{|c|}{ Study group: $Z=53.85\left(P=0.001^{*}\right)$, control group: $Z=0.05(P=0.974)$} \\
\hline
\end{tabular}


Table (6): Effect of educational program on diet and weight among study and control group at three phases: before, at first and second evaluations.

\begin{tabular}{|c|c|c|c|c|c|c|c|c|c|c|c|c|c|c|c|}
\hline \multirow{3}{*}{ Diet and weight } & \multicolumn{5}{|c|}{ Before program } & \multicolumn{5}{|c|}{ At First evaluation } & \multicolumn{5}{|c|}{ At Second evaluation } \\
\hline & \multicolumn{2}{|c|}{$\begin{array}{c}\text { Study group } \\
(\mathrm{n}=54)\end{array}$} & \multicolumn{2}{|c|}{$\begin{array}{c}\text { Control group } \\
(\mathrm{n}=54)\end{array}$} & \multirow{2}{*}{ Pvalue } & \multicolumn{2}{|c|}{$\begin{array}{c}\text { Study group } \\
(\mathrm{n}=54)\end{array}$} & \multicolumn{2}{|c|}{$\begin{array}{c}\text { Control group } \\
(\mathrm{n}=54)\end{array}$} & \multirow{2}{*}{$\begin{array}{c}\text { P } \\
\text { Value }\end{array}$} & \multicolumn{2}{|c|}{$\begin{array}{c}\text { Study group } \\
(\mathrm{n}=54)\end{array}$} & \multicolumn{2}{|c|}{$\begin{array}{c}\text { Control group } \\
(\mathrm{n}=54)\end{array}$} & \multirow{2}{*}{$\begin{array}{c}P \\
\text { value }\end{array}$} \\
\hline & No. & $\%$ & No. & $\%$ & & No. & $\%$ & & $\%$ & & No. & $\%$ & No. & $\%$ & \\
\hline \multicolumn{16}{|l|}{ Place of having meals } \\
\hline Athome & 49 & 90.7 & 48 & 88.9 & \multirow{3}{*}{0.22} & 51 & 94.4 & 45 & 83.3 & \multirow{3}{*}{0.12} & 51 & 94.4 & 48 & 88.9 & \multirow{3}{*}{0.29} \\
\hline Atrestaurant & 2 & 3.7 & 0 & 0.0 & & 0 & 0.0 & 3 & 5.6 & & 0 & 0.0 & 0 & 0.0 & \\
\hline Atwork & 3 & 5.6 & 6 & 11.1 & & 3 & 5.6 & 6 & 11.1 & & 3 & 5.6 & 6 & 11.1 & \\
\hline Sig. & \multicolumn{15}{|c|}{ Study group: $Z=1.41(P=0.15)$, control group: $Z=0.001(P=1.0)$} \\
\hline \multicolumn{16}{|c|}{ Person who chooses the meals } \\
\hline Wife & 35 & 64.8 & 45 & 83.3 & \multirow{3}{*}{$0.019^{*}$} & 33 & 61.1 & 45 & 83.3 & \multirow{3}{*}{$0.005^{*}$} & 33 & 61.1 & 45 & 83.3 & \multirow{3}{*}{$0.005^{*}$} \\
\hline Mother & 6 & 11.1 & 0 & 0.0 & & 8 & 14.8 & 0 & 0.0 & & 8 & 14.8 & 0 & 0.0 & \\
\hline One of sons & 13 & 24.1 & 9 & 16.7 & & 13 & 24.1 & 9 & 16.7 & & 13 & 24.1 & 9 & 16.7 & \\
\hline Sig. & \multicolumn{15}{|c|}{ Study group: $Z=1.41(P=0.15)$, control group: $Z=0.001(P=1.0)$} \\
\hline \multicolumn{16}{|l|}{ Number of meals/day } \\
\hline One & 8 & 14.8 & 0 & 0.0 & \multirow{4}{*}{$0.001^{*}$} & 0 & 0.0 & 8 & 14.8 & \multirow{4}{*}{$0.001^{*}$} & 2 & 3.7 & 8 & 14.8 & \\
\hline Two & 27 & 50.0 & 16 & 29.6 & & 11 & 20.4 & 36 & 66.7 & & 12 & 22.2 & 36 & 66.7 & \\
\hline Three & 19 & 35.2 & 38 & 70.4 & & 41 & 75.9 & 10 & 18.5 & & 38 & 70.4 & 10 & 18.5 & $0.001^{8}$ \\
\hline Six & 0 & 0.0 & 0 & 0.0 & & 2 & 3.7 & 0 & 0.0 & & 2 & 3.7 & 0 & 0.0 & \\
\hline Sig. & & & & & Study gro & $Z=5$ & $P=0$ & 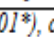 & trol gron & $Z=2.97(\mathrm{t}$ & $\left.003^{*}\right)$ & & & & \\
\hline Eatingpr & & & & & & & & & & & & & & & \\
\hline Large infrequent meals & 36 & 66.7 & 12 & 22.2 & & 52 & 96.3 & 15 & 27.8 & & 52 & 96.3 & 15 & 27.8 & \\
\hline Small frequent meals & 18 & 33.3 & 42 & 77.8 & $.001^{*}$ & 2 & 3.7 & 39 & 72.2 & $0.001^{*}$ & 2 & 3.7 & 39 & 72.2 & $0.001^{*}$ \\
\hline Sig. & & & & & Study g & up: $Z=$ & $0(P=0$ & $\left.01^{*}\right)$, & trol gro & $Z=1.73$ & & & & & \\
\hline Use excessive salt in foo & & & & & & & & & & & & & & & \\
\hline Yes & 22 & 40.7 & 20 & 37.0 & & 6 & 11.1 & 18 & 33.3 & & 7 & 13.0 & 18 & 33.3 & \\
\hline No & 32 & 59.3 & 34 & 63.0 & 0.693 & 48 & 88.9 & 36 & 66.7 & $0.003^{8}$ & 47 & 87.0 & 36 & 66.7 & $0.012^{*}$ \\
\hline Sig. & & & & & Study $g r c$ & $z: Z=$ & $57(P=$ & $\left..001^{*}\right)$ & entrolgr & $Z=0.22$ & $0.89)$ & & & & \\
\hline Use excessive fat in food & & & & & & & & & & & & & & & \\
\hline Yes & 17 & 31.5 & 41 & 75.9 & & 9 & 16.7 & 40 & 74.1 & & 3 & 5.6 & 40 & 74.1 & \\
\hline No & 37 & 68.5 & 13 & 24.1 & $0.001^{*}$ & 45 & 83.3 & 14 & 25.9 & $0.001^{*}$ & 51 & 94.4 & 14 & 25.9 & $0.001^{*}$ \\
\hline Sig. & & & & & Study, & $Z=$ & $43(P=$ & $\left..001^{*}\right)$ & entrolg & $Z=0$ & & & & & \\
\hline
\end{tabular}

Table (6)..... (cont)

\begin{tabular}{|c|c|c|c|c|c|c|c|c|c|c|c|c|c|c|c|}
\hline \multirow{3}{*}{ Activities } & \multicolumn{5}{|c|}{ Before program } & \multicolumn{5}{|c|}{ At First evaluation } & \multicolumn{5}{|c|}{ At Second evaluation } \\
\hline & \multicolumn{2}{|c|}{$\begin{array}{c}\text { Study group } \\
(\mathrm{n}=54)\end{array}$} & \multicolumn{2}{|c|}{$\begin{array}{l}\text { Control } \\
\text { group } \\
(\mathrm{n}=54)\end{array}$} & \multirow[t]{2}{*}{$P$ value } & \multicolumn{2}{|c|}{$\begin{array}{l}\text { Study group } \\
\quad(n=54)\end{array}$} & \multicolumn{2}{|c|}{$\begin{array}{l}\text { Control } \\
\text { group } \\
(\mathrm{n}=54)\end{array}$} & \multirow[t]{2}{*}{$\begin{array}{c}P \\
\text { value }\end{array}$} & \multicolumn{2}{|c|}{$\begin{array}{c}\text { Study group } \\
(n=54)\end{array}$} & \multicolumn{2}{|c|}{$\begin{array}{l}\text { Control } \\
\text { group } \\
(\mathrm{n}=54)\end{array}$} & \multirow[t]{2}{*}{$\begin{array}{c}P \\
\text { value }\end{array}$} \\
\hline & No. & $\%$ & No. & $\%$ & & No. & $\%$ & No. & $\%$ & & No. & $\%$ & No. & $\%$ & \\
\hline \multicolumn{16}{|c|}{ Hobbies and entertainments } \\
\hline Yes & 32 & 59.3 & 42 & 77.8 & \multirow{2}{*}{$0.038^{*}$} & 50 & 92.6 & 49 & 90.8 & \multirow{2}{*}{1.0} & 50 & 92.6 & 49 & 90.7 & \multirow{2}{*}{1.0} \\
\hline No & 22 & 40.7 & 12 & 22.2 & & 4 & 7.4 & 5 & 9.3 & & 4 & 7.4 & 5 & 9.3 & \\
\hline Sig. & \multicolumn{15}{|c|}{ Study group: $Z=26.51\left(P=0.001^{*}\right)$, control group: $Z=5.15(P=0.076)$} \\
\hline \multicolumn{16}{|c|}{ If the disease affects your work } \\
\hline Yes & 47 & 92.1 & 44 & 89.8 & \multirow{2}{*}{0.738} & 48 & 94.1 & 44 & 89.8 & \multirow{2}{*}{0.483} & 44 & 86.3 & 44 & 89.8 & \multirow{2}{*}{0.588} \\
\hline No & 4 & 7.8 & 5 & 10.2 & & 3 & 5.9 & 5 & 10.2 & & 7 & 13.7 & 5 & 10.2 & \\
\hline Sig. & \multicolumn{15}{|c|}{ Study group: $Z=2.04(P=0.359)$, control group: $Z=0.0(P=1.0)$} \\
\hline \multicolumn{16}{|c|}{ Do you take rest during work } \\
\hline Yes & 45 & 88.2 & 22 & 44.9 & \multirow{2}{*}{$0.001^{*}$} & 46 & 90.2 & 23 & 47 & \multirow{2}{*}{$0.0001^{*}$} & 42 & 82.3 & 23 & 47 & \multirow{2}{*}{$0.001^{*}$} \\
\hline No & 6 & 11.8 & 27 & 55.1 & & 5 & 9.8 & 26 & 53.1 & & 9 & 17.6 & 26 & 53.1 & \\
\hline Sig. & \multicolumn{15}{|c|}{ Study group: $1.5(P=0.473)$, control group: $Z=0.05(P=0.973)$} \\
\hline Additional work & & & & & & & & & & & & & & & \\
\hline Yes & 3 & 5.9 & 5 & 10.2 & 0,03 & 7 & 13.7 & 5 & 10.2 & 0.500 & 4 & 7.8 & 5 & 10.2 & \\
\hline No & 48 & 94.1 & 44 & 89.8 & 0.483 & 44 & 86.3 & 44 & 89.8 & 0.588 & 47 & 92.2 & 44 & 89.8 & 0.738 \\
\hline Sig. & & & & & Study & up: $Z$ & $04(P=$ & 359), & atrolg & $Z=0.27$ & 873) & & & & \\
\hline Decreasing load o & by othe & & & & & & & & & & & & & & \\
\hline Yes & 26 & 50.9 & 13 & 26.5 & & 28 & 54.9 & 13 & 26.5 & & 32 & 62.7 & 15 & 30.6 & \\
\hline No & 25 & 49 & 36 & 73.5 & $0.012^{*}$ & 23 & 45.1 & 36 & 73.5 & $0.004^{*}$ & 19 & 37.3 & 34 & 69.4 & $0.001^{*}$ \\
\hline Sig. & & & & & Study \& & oup: $Z$ & $49(P=$ & 475), & ntrolg & $Z=0.27$ & .873) & & & & \\
\hline Doyou work as y & & & & & & & & & & & & & & & \\
\hline Yes & 46 & 85.2 & 54 & 100 & & 50 & 92.6 & 54 & 100 & & 50 & 92.6 & 54 & 100 & \\
\hline No & 8 & 14.8 & 0 & 0 & $0.005^{*}$ & 4 & 7.4 & 0 & 0 & 0.118 & 4 & 7.4 & 0 & 0 & 0.118 \\
\hline Sig. & & & & & & tudy g & $p: Z=2$ & $2(P=$ & (29), cc & group: $\Lambda$ & & & & & \\
\hline
\end{tabular}


Table (6).... (cont)

\begin{tabular}{|c|c|c|c|c|c|c|c|c|c|c|c|c|c|c|c|}
\hline \multirow{3}{*}{ Diet and weight } & \multicolumn{5}{|c|}{ Before program } & \multicolumn{5}{|c|}{ At First evaluation } & \multicolumn{5}{|c|}{ At Second evaluation } \\
\hline & \multicolumn{2}{|c|}{$\begin{array}{c}\text { Study group } \\
(\mathrm{n}=54)\end{array}$} & \multicolumn{2}{|c|}{$\begin{array}{l}\text { Control group } \\
\qquad(\mathrm{n}=54)\end{array}$} & \multirow[t]{2}{*}{$P$ value } & \multicolumn{2}{|c|}{$\begin{array}{l}\text { Study group } \\
\qquad(\mathrm{n}=54)\end{array}$} & \multicolumn{2}{|c|}{$\begin{array}{c}\text { Control group } \\
(n=54)\end{array}$} & \multirow[t]{2}{*}{$\begin{array}{c}P \\
\text { Value }\end{array}$} & \multicolumn{2}{|c|}{$\begin{array}{c}\text { Study group } \\
(\mathrm{n}=54)\end{array}$} & \multicolumn{2}{|c|}{$\begin{array}{l}\text { Control group } \\
\qquad(\mathrm{n}=54)\end{array}$} & \multirow[t]{2}{*}{$\begin{array}{c}P \\
\text { value }\end{array}$} \\
\hline & No. & $\%$ & No. & $\%$ & & No. & $\%$ & No. & $\%$ & & No. & $\%$ & No. & $\%$ & \\
\hline \multicolumn{16}{|c|}{ Use easy digestible food } \\
\hline Yes & 51 & 94.5 & 33 & 61.1 & \multirow{2}{*}{$0.001^{*}$} & 47 & 87.1 & 32 & 59.2 & \multirow{2}{*}{$0.001^{*}$} & 50 & 92.6 & 33 & 61.1 & \multirow{2}{*}{$0.001^{*}$} \\
\hline No & 3 & 5.6 & 21 & 38.9 & & 7 & 13 & 22 & 40.7 & & 4 & 7.4 & 21 & 38.9 & \\
\hline Sig. & \multicolumn{15}{|c|}{ Study group: $Z=2.03(P=0.362)$, control group: $Z=0.05(P=0.975)$} \\
\hline \multicolumn{16}{|c|}{ Eating unhealthy foods } \\
\hline Yes & 40 & 74 & 42 & 77.8 & \multirow{2}{*}{0.652} & 6 & 11.2 & 40 & 74.1 & \multirow{2}{*}{$0.001^{*}$} & 22 & 40.8 & 49 & 90.8 & \multirow{2}{*}{$0.001^{*}$} \\
\hline No & 14 & 25.9 & 12 & 22.2 & & 48 & 88.9 & 14 & 25.9 & & 32 & 59.3 & 5 & 9.3 & \\
\hline Sig- & \multicolumn{15}{|c|}{ Study group: $Z=44.0\left(P=0.001^{*}\right)$, control group: $Z=5.35(P=0.069)$} \\
\hline \multicolumn{16}{|c|}{ Follow diet after discharge } \\
\hline Yes & 48 & 88.9 & 33 & 61.1 & \multirow{2}{*}{$0.001^{*}$} & 51 & 94.5 & 33 & 61.1 & \multirow{2}{*}{$0.001^{*}$} & 53 & 98.1 & 33 & 61.1 & \multirow{2}{*}{$0.001^{*}$} \\
\hline No & 6 & 11.1 & 21 & 38.9 & & 3 & 5.6 & 21 & 38.9 & & 1 & 1.9 & 21 & 38.9 & \\
\hline Sig- & & & & & Stuc & roup: & $4.05(F$ & $0.13)$, & trol grot & $: Z=0.001$ & $P=1.0)$ & & & & \\
\hline \multicolumn{16}{|c|}{ Feel diet regimen is a problem } \\
\hline Yes & 43 & 79.6 & 47 & 87.1 & 0.302 & 30 & 55.5 & 47 & 87.1 & $0,001 *$ & 39 & 72.2 & 47 & 87.1 & 0.056 \\
\hline No & 11 & 20.4 & 7 & 13 & 0.502 & 24 & 44.4 & 7 & 13 & $0.001^{\circ}$ & 15 & 27.8 & 7 & 13 & 0.050 \\
\hline Sig. & & & & & Stud & roup: 2 & $7.7(P=$ & $\left.021^{*}\right)$ & terol gro & $p: Z=0.001$ & $P=1.0$ & & & & \\
\hline Received medical k & ledg & bout d & & & & & & & & & & & & & \\
\hline Yes & 35 & 64.9 & 30 & 55.5 & & 40 & 74.1 & 30 & 55.5 & & 40 & 74.1 & 30 & 55.5 & \\
\hline No & 19 & 35.2 & 24 & 44.4 & 0.326 & 14 & 25.9 & 24 & 44.4 & $0.044^{\circ}$ & 14 & 25.9 & 24 & 44.4 & $0.044^{*}$ \\
\hline Sig- & & & & & Stuc & roup: & $1.5(P=$ & 473), & trol grot & $: Z=0.001$ & $P=1.0)$ & & & & \\
\hline Weight is controlled & & & & & & & & & & & & & & & \\
\hline Yes & 24 & 44.4 & 25 & 46.3 & 0.847 & 36 & 66.7 & 25 & 46.3 & $0033 *$ & 36 & 66.7 & 30 & 55.5 & 0236 \\
\hline No & 30 & 55.6 & 29 & 53.7 & 0.847 & 18 & 33.3 & 29 & 53.7 & $0.033^{\circ}$ & 18 & 33.3 & 24 & 44.4 & 0.250 \\
\hline Sig- & & & & & Stud & $u p: Z$ & $36(P=$ & $025^{*}$, & atrol gr & $Z=1.23$ & $=0.539$ & & & & \\
\hline
\end{tabular}

Sig.: statistical test between same group at different timing * *significant at $P \leq 0.05$

Table (6): (cont)

\begin{tabular}{|c|c|c|c|c|c|c|c|c|c|}
\hline \multirow{3}{*}{ Diet and weight } & \multicolumn{3}{|c|}{ Before program } & \multicolumn{3}{|c|}{ At First evaluation } & \multicolumn{3}{|c|}{ At Second evaluation } \\
\hline & $\begin{array}{l}\text { Study group } \\
\qquad(\mathrm{n}=54)\end{array}$ & $\begin{array}{l}\text { Control } \\
\text { group } \\
(n=54)\end{array}$ & \multirow[t]{2}{*}{$P$ value } & $\begin{array}{l}\text { Study group } \\
\quad(n=54)\end{array}$ & $\begin{array}{l}\text { Control } \\
\text { group } \\
(n=54)\end{array}$ & \multirow[t]{2}{*}{$\begin{array}{c}\mathrm{P} \\
\text { value }\end{array}$} & $\begin{array}{l}\text { Study group } \\
\qquad(n=54)\end{array}$ & $\begin{array}{l}\text { Control } \\
\text { group } \\
(n=54)\end{array}$ & \multirow[t]{2}{*}{$\begin{array}{c}\mathrm{P} \\
\text { value }\end{array}$} \\
\hline & No. $\%$ & No. $\%$ & & No. $\%$ & No. $\%$ & & No. $\%$ & No. $\%$ & \\
\hline \multicolumn{10}{|l|}{ Weight is controlled } \\
\hline Yes & $24 \quad 44.4$ & $25 \quad 46.3$ & \multirow{2}{*}{0.847} & $\begin{array}{ll}36 & 66.7\end{array}$ & $\begin{array}{ll}25 & 46.3\end{array}$ & \multirow{2}{*}{$0.033^{*}$} & $\begin{array}{ll}36 & 66.7 \\
\end{array}$ & $30 \quad 55.5$ & \multirow{2}{*}{0.236} \\
\hline $\mathrm{No}$ & $30 \quad 55.6$ & $\begin{array}{ll}29 & 53.7\end{array}$ & & $\begin{array}{ll}18 & 33.3\end{array}$ & $\begin{array}{ll}29 & 53.7\end{array}$ & & \begin{tabular}{|ll}
18 & 33.3 \\
\end{tabular} & $24 \quad 44.4$ & \\
\hline Sig. & \multicolumn{9}{|c|}{ Study group: $Z=7.36\left(P=0.025^{*}\right)$, control group: $Z=1.23(P=0.539)$} \\
\hline \multicolumn{10}{|l|}{ Regular weight checking } \\
\hline Yes & $32 \quad 66.7$ & $25 \quad 52.1$ & \multirow{2}{*}{0.146} & 68.6 & $25 \quad 47.2$ & \multirow{2}{*}{$0.027^{*}$} & 66.7 & $30 \quad 56.6$ & \multirow{2}{*}{0.292} \\
\hline No & $\begin{array}{ll}16 & 33.3\end{array}$ & $23 \quad 47.9$ & & $16 \quad 31.4$ & $28 \quad 52.8$ & & $17 \quad 33.3$ & $23 \quad 43.4$ & \\
\hline Sig. & \multicolumn{9}{|c|}{ Study group: $Z=0.06(P=0.971)$, control group: $Z=0.95(P=0.623)$} \\
\hline
\end{tabular}


Table (7): Effect of the educational program on risky habits (smoking habit and alcohol consumption) among study and control group at three phases: before, at first and second evaluations.

\begin{tabular}{|c|c|c|c|c|c|c|c|c|c|c|c|c|c|c|}
\hline \multirow{3}{*}{$\begin{array}{c}\text { Use of } \\
\text { medications }\end{array}$} & \multicolumn{5}{|c|}{ Before program } & \multicolumn{4}{|c|}{ At First evaluation } & \multicolumn{5}{|c|}{ At Second evaluation } \\
\hline & \multicolumn{2}{|c|}{$\begin{array}{c}\text { Study group } \\
(\mathrm{n}=54)\end{array}$} & \multicolumn{2}{|c|}{$\begin{array}{c}\text { Control group } \\
(n=54)\end{array}$} & \multirow[b]{2}{*}{$P$ value } & $\begin{array}{c}\text { Study group } \\
(\mathrm{n}=54)\end{array}$ & \multicolumn{2}{|c|}{$\begin{array}{c}\text { Control group } \\
(n=54)\end{array}$} & \multirow[t]{2}{*}{$\begin{array}{c}P \\
\text { value }\end{array}$} & \multicolumn{2}{|c|}{$\begin{array}{c}\text { Study group } \\
(\mathrm{n}=54)\end{array}$} & \multicolumn{2}{|c|}{$\begin{array}{c}\text { Control group } \\
(n=54)\end{array}$} & \multirow[t]{2}{*}{$\begin{array}{c}P \\
\text { value }\end{array}$} \\
\hline & No. & $\%$ & No. & $\%$ & & No. $\%$ & No. & $\%$ & & No. & $\%$ & No. & $\%$ & \\
\hline \multicolumn{15}{|c|}{ Know medication and its doses } \\
\hline Yes & 35 & 64.8 & 46 & 85.2 & \multirow{2}{*}{$0.015^{*}$} & 88.9 & 46 & 85.2 & \multirow{2}{*}{0.567} & 49 & 90.8 & 46 & 85.2 & \multirow{2}{*}{0.375} \\
\hline No & 19 & 35.2 & 8 & 14.8 & & 11.1 & 8 & 14.8 & & 5 & 9.3 & 8 & 14.8 & \\
\hline Sig. & \multicolumn{14}{|c|}{ Study group: $Z=14.97\left(P=0.001^{*}\right)$, control group: $Z=0.001(P=1.0)$} \\
\hline \multicolumn{15}{|c|}{ Feel better after receiving medications } \\
\hline Yes & 54 & 100 & 54 & 100 & \multirow{2}{*}{$-\mathrm{NA}-$} & 94.4 & 54 & 100 & \multirow{2}{*}{0.243} & 54 & 100 & 54 & 100 & \multirow{2}{*}{$-\mathrm{NA}-$} \\
\hline No & 0 & 0 & 0 & 0 & & 5.6 & 0 & 0 & & 0 & 0 & 0 & 0 & \\
\hline Sig. & & & & & & udy group: $Z=6.1$ & $(P=0$ & *), cont & group: $\lambda$ & & & & & \\
\hline \multicolumn{15}{|c|}{ Suffer from side effects of medications } \\
\hline Yes & 54 & 100 & 54 & 100 & \multirow{2}{*}{-NA- } & 90.7 & 54 & 100 & \multirow{2}{*}{0.057} & 53 & 98.2 & 54 & 100 & \multirow{2}{*}{1.0} \\
\hline No & 0 & 0 & 0 & 0 & & 9.3 & 0 & 0 & & 1 & 1.9 & 0 & 0 & \\
\hline Sig. & & & & & & uay group: $Z=7.2$ & $(P=0$. & *), cont & group: 1 & & & & & \\
\hline \multicolumn{15}{|c|}{ Take overd ose of medication without consulting the physician } \\
\hline Yes & 23 & 42.6 & 20 & 37 & \multirow{2}{*}{0.556} & 13 & 18 & 33.3 & $0.012 *$ & 7 & 13 & 18 & 33.3 & $0,012 *$ \\
\hline No & 31 & 57.4 & 34 & 63 & & 47 & 36 & 66.7 & $0.012^{\circ}$ & 47 & 87 & 36 & 66.7 & $0.012^{\circ}$ \\
\hline Sig. & & & & & Study g & $p: Z=17.93(P=0$ & $\left.01^{*}\right)$, & trol gron & $Z=0.22$ & 0.897 & & & & \\
\hline Know that medic & ns wi & taken & arough & twhole & & & & & & & & & & \\
\hline Yes & 49 & 90.8 & 53 & 98.2 & 0205 & 100 & 54 & 100 & NA & 54 & 100 & 54 & 100 & NA \\
\hline No & 5 & 9.3 & 1 & 1.9 & 0.205 & 0 & 0 & 0 & -NA- & 0 & 0 & 0 & 0 & $-\mathrm{NA}-$ \\
\hline Sig. & & & & & Studyg & $p: Z=10.32(P=0$ & $\left.06^{*}\right)$, & rol gron & $Z=2.01$ & 0.366 & & & & \\
\hline Feel depressed be & iseyo & ill rece & medi & ons thr & ghout life & & & & & & & & & \\
\hline Yes & 53 & 98.2 & 54 & 100 & $\mathrm{NA}$ & 90.7 & 54 & 100 & 0057 & 52 & 96.3 & 54 & 100 & 0.495 \\
\hline No & 1 & 1.9 & 0 & 0 & -NA- & 9.3 & 0 & 0 & 0.037 & 2 & 3.7 & 0 & 0 & 0.493 \\
\hline Sig. & & & & & & tudy group: $Z=3$. & $(P=0$ & ) contr & group: $N$ & & & & & \\
\hline
\end{tabular}

Table (7)..... (cont)

\begin{tabular}{|c|c|c|c|c|c|c|c|c|c|}
\hline \multirow{3}{*}{ Use of medications } & \multicolumn{3}{|c|}{ Before program } & \multicolumn{3}{|c|}{ "At First evaluation } & \multicolumn{3}{|c|}{ At Second evaluation } \\
\hline & $\begin{array}{l}\text { Study } \\
\text { group } \\
(\mathrm{n}=54)\end{array}$ & $\begin{array}{c}\text { Controlgroup } \\
(\mathrm{n}=54)\end{array}$ & \multirow[t]{2}{*}{$\begin{array}{c}P \\
\text { value }\end{array}$} & $\begin{array}{l}\text { Study } \\
\text { group } \\
(\mathrm{n}=54)\end{array}$ & $\begin{array}{l}\text { Control group } \\
\qquad(\mathrm{n}=54)\end{array}$ & \multirow[t]{2}{*}{$\begin{array}{c}P \\
\text { value }\end{array}$} & $\begin{array}{l}\text { Study } \\
\text { group } \\
(n=54)\end{array}$ & $\begin{array}{l}\text { Control group } \\
\qquad(\mathrm{n}=54)\end{array}$ & \multirow[t]{2}{*}{$\begin{array}{c}P \\
\text { value }\end{array}$} \\
\hline & No. $\%$ & No. $\%$ & & No. $\%$ & No. & & No. $\%$ & No. & \\
\hline \multicolumn{10}{|c|}{ Receive health education from the medical team about medication use } \\
\hline Yes & $40 \quad 74.1$ & $31 \quad 57.4$ & \multirow{2}{*}{0.068} & $54 \quad 100$ & 61.1 & \multirow{2}{*}{$0.001^{*}$} & $54 \quad 100$ & 61.1 & \multirow{2}{*}{$0.001^{*}$} \\
\hline No & $14 \quad 25.9$ & $23 \quad 42.6$ & & 0 & 38.9 & & 0 & 38.9 & \\
\hline Sig. & & & & $=30.6$. & $11^{*}, \mathrm{co}$ & $Z=$ & $(P=0.902)$ & & \\
\hline
\end{tabular}


Table (8): Effect of educational program on use of medications among study and control group at three phases: before, first and second evaluations.

Second evaluations.

\begin{tabular}{|c|c|c|c|c|c|c|c|c|c|c|c|c|c|c|c|}
\hline \multirow{3}{*}{ Risky habits } & \multicolumn{5}{|c|}{ Before program } & \multicolumn{5}{|c|}{ At First evaluation } & \multicolumn{5}{|c|}{ At Second evaluation } \\
\hline & \multicolumn{2}{|c|}{$\begin{array}{l}\text { Study } \\
\text { group } \\
(\mathrm{n}=54)\end{array}$} & \multicolumn{2}{|c|}{$\begin{array}{l}\text { Control } \\
\text { group } \\
(\mathrm{n}=54)\end{array}$} & \multirow[t]{2}{*}{$P$ value } & \multicolumn{2}{|c|}{$\begin{array}{l}\text { Study } \\
\text { group } \\
(\mathrm{n}=54)\end{array}$} & \multicolumn{2}{|c|}{$\begin{array}{c}\text { Control group } \\
(n=54)\end{array}$} & \multirow[t]{2}{*}{$\begin{array}{c}\mathrm{P} \\
\text { value }\end{array}$} & \multicolumn{2}{|c|}{$\begin{array}{l}\text { Study } \\
\text { group } \\
(\mathrm{n}=54)\end{array}$} & \multicolumn{2}{|c|}{$\begin{array}{l}\text { Control } \\
\text { group } \\
(\mathrm{n}=54)\end{array}$} & \multirow[t]{2}{*}{$\begin{array}{c}P \\
\text { value }\end{array}$} \\
\hline & No. & $\%$ & No. & $\%$ & & No. & $\%$ & No. & $\%$ & & No. & & No. & $\%$ & \\
\hline \multicolumn{16}{|l|}{ Smoking habit } \\
\hline Smoker & 19 & 35.2 & 20 & 37 & 0.84 & 0 & 0 & 18 & 36.7 & $0.001^{*}$ & 0 & 0 & 18 & 36.7 & $0.001^{*}$ \\
\hline \multicolumn{16}{|l|}{ Decreased smoking } \\
\hline Yes & 11 & 57.9 & 0 & 0 & \multirow{2}{*}{$0.001^{*}$} & 19 & 100 & 2 & 10 & \multirow{2}{*}{$0.001^{*}$} & 19 & 100 & 2 & 10 & \multirow{2}{*}{$0.001^{*}$} \\
\hline No & 8 & 42.1 & 20 & 100 & & 0 & 0 & 18 & 90 & & 0 & 0 & 18 & 90 & \\
\hline \multicolumn{16}{|c|}{ Know hazards of smoking } \\
\hline Yes & 41 & 80.4 & 21 & 42.9 & \multirow{2}{*}{$0.001^{*}$} & 50 & 98 & 28 & 57.1 & \multirow{2}{*}{$0.001^{*}$} & 50 & 98 & 28 & 57.1 & \multirow{2}{*}{$0.001^{*}$} \\
\hline No & 10 & 19.6 & 28 & 57.1 & & 1 & 2 & 21 & 42.9 & & 1 & 2 & 21 & 42.9 & \\
\hline Stop trials to quit smo & & & & & & & & & & & & & & & \\
\hline Yes & 11 & 52.4 & 0 & 0 & $0,001^{*}$ & 19 & 90.5 & 2 & 10 & $0.001^{*}$ & 19 & 90.5 & 2 & 10 & $0.001^{*}$ \\
\hline No & 10 & 47.6 & 20 & 100 & $0.001^{-2}$ & 2 & 9.5 & 18 & 90 & 0.001 & 2 & 9.5 & 18 & 90 & 0.001 \\
\hline Alcohol consumption & & & & & & & & & & & & & & & \\
\hline Drink alcohols & & & & & & & & & & & & & & & \\
\hline Yes & 1 & 1.9 & 0 & 0 & 10 & 1 & 1.9 & 0 & 0 & 10 & 1 & 1.9 & 0 & 0 & 10 \\
\hline No & 53 & 98.1 & 54 & 100 & & 53 & 98.1 & 54 & 100 & 1.0 & 53 & 98.1 & 54 & 100 & 1.0 \\
\hline know hazards of alcoh & & & & & & & & & & & & & & & \\
\hline Yes & 36 & 66.7 & 47 & 87.1 & $0.012^{*}$ & 46 & 85.2 & 54 & 100 & $0.006^{*}$ & 47 & 87 & 54 & 100 & $0.013^{*}$ \\
\hline No & 18 & 33.3 & 7 & 13 & 0.012 & 8 & 14.8 & 0 & $0.00 \%$ & 0.000 & 7 & 13 & 0 & 0 & 0.015 \\
\hline
\end{tabular}

significant at $P \leq 0.05$

\section{DISCUSSION:}

Congestive heart failure is a long-term illness, that is characterized by multiple problems for patients and their families. Therefore, it is very important that patients know information to cope with their problems as following the prescribed therapeutic regimen which includes life style modifications related to diet, activity and medication (Lakdizaji et al., 2013). Recognition and treatment of problems are priorities of care for patients with chronic illness such as congestive heart failure (Richman, 2010).

Knopp (2009); Delaney et al. (2011) mentioned that nurses can provide assistance and information to patients and their families while in hospital by discussing with them some of the common problems which patients may experience once they return home. It is important as well for nurses to be aware of the feelings and needs of the spouse or career. According to Thompson (2010), the importance of individualizing a plan of care before discharge should include home care for provision of long-term education and counseling.

The results of the present study revealed that age of most of the patients in both control and study groups was 60 years old and more. This result is supported by Karlsson (2011), who found that the congestive heart failure is more common in aged persons over 65 year. Moreover, American Heart Society (2012); Cardiology 
Channel (2012), found that congestive heart failure is more common in persons aged between 40 to 55 years old, while Morgan \& Naka (2013) reported that, age and gender are major factors in developing heart disease. Additionally, prevalence of CHF is increased in older people particularly after 45 years of age.

In relation to gender, it was found that the majority of the studied patients in both control and study groups were male patients. This fact may be explained by increase of smoking habit among men, in addition to occupational factor that need increased physical work. This result was explained by Lakdizaji et al. (2013) who found that during a study examined data from general practices of 2.1 million patients, age related prevalence of heart failure was 9.7 per 1.000 males and 8.2 per 1.000 females.

Regarding the marital status, it was found that majority of studied patients in both control and study groups were married, this finding goes in the line with Elsayed (2004); Reddy et al. (2010), who found that married patients represented the higher percentage compared to single, divorced and widow patients. So, stress of the family obligation could be a contributing factor to develop CHF.

In relation to educational level, the current study revealed that less than half of the subjects were able to read and write in each group. Additionally, the majority of the study subjects were laborers, with limited education. Similarly, Moore et al. (2014), reported that educational level is considered a personal issue which influences the individual ability to cope with the disease. While, Lakdizaji et al. (2013) reported that the level of education is important for CHF patients to perceive information.

Regarding family income, more than half of the subjects in both control and study groups earned less than $300 \mathrm{LE}$ as monthly income. Also more than half them had insufficient income to cover the cost of treatment. However, less than half of the subjects were been supported by health insurance. Coyle \& Berger (2013), stated that lower socio-economic status and low income are associated with increased occurrence of chronic heart disease in both men and women probably due in part to the higher prevalence of CHF risk factors.

Regarding knowledge about history of disease, the majority of the subjects involved in both study and control group had incomplete knowledge about their own diagnosis, which includes definition, causes, types and complications of CHF. Such result in supported by Khan (2006); Gerdes \& Lorenz (2013), as they found that the majority of patients with CHF were concerned about causes and manifestations while only a minority were concerned about diagnosis, prevention and complications of CHF. While Colet et al. (2014), stated that, only a small portion of the study sample was able to correctly answer CHF knowledge questions that entailed prevention of the disease.

The present study shows that household activities, change observed among study group was increased as the percentage who reported increased in the follow up phase (3 months post intervention), compared to among control group. Differences observed 
between study and control group so as differences observed at different times of evaluation were statistically significant. Lakdizaji et al. (2013); Weber \& Kelley (2014) found that, the patients reported waiting for a few minutes to perform any activity, completing activities at a slower pace, were resting between activities, or staying quiet and patients tried to move slowly and carefully, avoiding the climbing of stairs .Some patients did not go out of the house and a few patients increased their activity. Patients said that to manage tiredness, "I force myself do some-thing"; "I just keep going"; and "The more I move around the better I feel".

Regarding self care behavior, it increased among the study group after this program significantly at the $2^{\text {nd }}$ evaluation. In comparison, no change of behavior occurred in control group at all evaluations. Differences between study and control groups were statistically significant .This finding is similar to the findings of Wang(2011); Bryant \& Gaspar (2014), who found that self- care behavior greatly increased at the second and third program intervention visits.

The current study revealed a highly statistically significant difference between both control and study groups, regarding taking rest during the work. The patients had less work hours per day and reported irregular attendance due to frequent absentees and sick leaves consequently decreased incentives. Also, it was found that all patients reported loss of social role, which may be due to frequent exacerbations of illness and recurrent hospital visits or admissions. This finding was supported by Sochalskl (2009); Lefteriotis (2013), who stated that the majority of patients had large number of social problems due to their chronic illness. The social office services should help the patients by placing them in suitable job according to their health status. Similarly, Abd El-Rahman (2002); Downing \& Gary (2011), reported that CHF in often associated with disability and is characterized by reduced activity tolerance. The high percentage of retired patients and those who changed their job nature due to illness indicated that $\mathrm{CHF}$ causes numerous problems on patients life.

The result of the present study showed that patients perceived diet regimen as a problem more than the control group. After the program intervention, such perception among the study group improved which is consistent with Wang (2011), who stated that patients with congestive heart failure suffer from lack of knowledge about the disease, proper diet, activity and self-care as well as impaired quality of life. The majority of the study and control group reported decreasing fatty diet, followed by low sodium intake. This result is consistent with Clevenger (2012) who found that every opportunity to provide education and counseling should be pursed whether it is during an inpatient hospital stay/or an outpatient clinic visit. Patient visits should always include dietary education on fat and sodium intake restriction, risk of alcohol consumption, and restriction of fluid intake.

The current study revealed no statistically significant difference between the control and study groups regarding weight control. This result was not supported by Clevenger (2012); Katz et al. (2015) who found that the change in body weight 
reported during weight loss program, was about $10 \%$ in 16 weeks among obese individuals undergoing diet regimen with or without exercise. Also they reported that the control group lost significant weight from baseline to follow-up (only, 4\%), which was found to be not statistically significantly different from the study group.

The current study revealed that a higher percentage of the study and control group suffered from side effects of medications at all timings. The percentage of those who suffered from side effects among the study group decreased significant immediately after the program. They complained of anorexia, nausea and headache, while the minority of them had diarrhea when taking any medication of treatments. This result was supported by Morgan \& Naka (2013) who found that all medications received for congestive heart failure may cause numerous side effects for patients.

The current study revealed a highly statistically significant difference in receiving health education from the medical team about medication use. Meanwhile, Albert (2012) reported that patients with CHF had full knowledge about medications they received including their name, dose, frequency, adverse effects. On other hand, this result also supported by Sherry (2013) who found that patients with CHF had low level of information regarding treatment received. The findings of the current study might be due to low level of education for the majority of patients included in both study and control group, subjects had some information about treatment because of program intervention, frequent readmission to hospital, health education received from the medical team about the prescribed medication.

The result of the current study revealed that knowledge about hazards of smoking increased among both groups after the program. Still nearly all the study groups were knowledgeable about the hazards after the program compared to the control group. Differences between both groups at all timings were statistically significant. This result was not in agreement with Ahmed (2003); Mark et al. (2014), who found that only a minority of patients were concerned about effect and hazards of smoking.

Regarding smoking habit, nearly equal percentage of smokers were found in both study and control group. Thus, insignificant difference was found between both groups before the program. After the program, no smokers were found among the study group while nearly no change was found among the control group. Trials to quit smoking had been reported to be significantly higher among the study group compared to the control group. This result was supported by Cardiology Channel (2012); McGee (2012) who found that quitting smoking decreases complications and progress of the disease thus helping for better prognosis. So, physicians recommend to stop smoking and frequent health education campaigns in mass media about its own health. This is similar to Goldberg (2010), who stated that quitting cigarette smoking is known to prolong life expectancy and improve quality of life.

In conclusion, nurses play important role to meet patient's information needs through 
different methods. Health education should be accustomed according to patient's condition, level of education, occupation, and socioeconomic condition. Indeed there is a need for continuing care of the CHF patient's after discharge. This result was supported by Karen (2009), who showed that the requirements of a good system of follow-up are the monitoring of patient symptoms, medication reviews, support in life style change and the provision of help if necessary. The patients must receive care and emotional support from their families. This reason comes in accordance with a study conducted by Clark et al. (2009), who stated that among the chronically ill, positive associations have been shown between information ,life satisfaction and social contact.

\section{CONCLUSION:}

Based on study findings, it can be concluded that:

Educational program has a significant improvement on health status outcome for patients congestive heart failure

\section{RECOMMENDATIONS:}

Patients and their families should be educated about $\mathrm{CHF}$, weight controlling and regular weight checking, decrease heart effort, prevention of infectious disease, physical activity, deep respiration exercise, avoid carrying heavy objects, regular checking of medical investigations, disease affects work and rest periods between activity, stress management and early warning signs during sexual relation .Developing the patient's information through using patients education booklet, a HF video, and written information sheet that the patients may take home each time they are seen in the hospital or clinic, also incorporating color picture flash cords of commonly used heart failure medication into initial and follow up teaching to assist patients in identifying medications and dosages. Specialty nursing programs to prepare nurses in different specialties to ensure high quality of information and care provided to patient. Replication of the current study on a large probability sample from different geographical areas to achieve more generalized results.

\section{REFERENCES:}

Abd El-Rahman AA. (2002): Discharge plan model for coronary artery disease patient. Thesis for the degree of Msc, Medical Surgical Nursing, Faculty of Nursing, Ain Shams University; P.p. 30-61.

Abu Donia SH. (1977): Educational program for patients with heart failure. Thesis for the degree of PHD, Medical Surgical Nursing, Faculty of Nursing, Alexandria University. 
Ahmed RE. (2003): Factors affecting of life for patient congestive heart failure. Thesis for the degree of Msc, Medical Surgical Nursing, Faculty of Nursing, Ain Shams University; P.p. 30-61.

Albert N. (2012):_Fluid management strategies in heart failure .Critical care Nurse, Vol .32, No 2; P.p. 20-33.

Albert N. (2013): Parallel paths to improve heart failure outcomes. American Journal of Critical Care. Vol. 22, No. 4; P.p. 289-297.

American Heart Society (2012): Heart failure, risk factors, Http:// www.failure.org / doctorate / CRI / content / CRI - 2-4-3-what - is - risk factors.

Amorim A., Miriam M. and Ribeiro T. (2013): Nursing diagnose and interventions for patients with congestive heart failure, Journal of the American College of Cardiology, 47(2); P.p. 7-380.

Andrietta M., Moreira R. and Barros A. (2011): Hospital discharge plan for patients with congestive heart failure. Rev. Latino-Am. Enfermagem, Vol 19, No. 6; P.p. 521445 .

Australian Institute of Health and Welfare. (2016): information and statistics to promote better health and wellbeing. http//www.aihw.gov.au/mal-health/health-status.

Bickiey L. and Szilagyip (2013): Guide to physical examination and history taking. 11th edition. Lippincott Williams and Wilkins.

Blecker S., Agarwal S. and Chang P. (2014): Quality of Care for Heart Failure Patients Hospitalized for Any Cause. Journal of the American College of Cardiology, Vol. 63, No.; P.p. 132-130.

Braun A. and Anderson M. (2011): Pathophysiology a clinical approach. Congestive Heart Failure, 2nd edition. Lippincott Williams and Wilkins.

Bryant R. and Gaspar PH. (2014): Implementation of a self-care of heart failure program among - based clients. Science Direct, Elsevier. Geriatric Nursing; P.p.1-6.

Butler J. (2012): An overview of chronic heart failure management. Nursing Practice, Vol. 108, No 14/15; P.p. 16-20.

Cardiology Channel (2012): Heart failure, clinical manifestation, Http:// www.cardiology channel.com / heart failure / clinical manifestation. html.

Clark A., Savard L. and Thompson D. (2009): Evidence for Heart Failure DiseaseManagement Programs, Journal of the American College of Cardiology. Vol. 54, No. 5; P.p. 397-401 . 
Clevenger SD. (2012): Effects of a randomized controlled trial of diet and exercise on objectively measured physically activity levels in older heart failure patients, Master Thesis, Faculty of science, Wake forest university; P.p. 64-68 .

Colet J., Rotellar J. and Vela E. (2014): Primary Care Program for Heart Failure. Rev Esp Cardiol. Vol .67, no 4; P.p. 283-293.

Coyle D. and Berger R. (2013): Cost-utility analysis of NT-pro BNP-guided multidisciplinary care in chronic heart failure. International Journal of Technology Assessment in Health Care, VOL. 3, NO 11; P.p1-29.

Damjanov I. (2012): Pathology for the heart professions. $4^{\text {th }}$ edition. ElsevierSaunders.

Delaney C., Apostolidis B. and Lachapelle L. (2011): Home care nurses' knowledge of evidence-based education topics for management of heart failure. Heart \& Lung journal, vol. 40; P.p. 285-292.

Downing J. and Gary J. (2011): The Role of Exercise Training in Heart Failure. Journal of the American College of Cardiology, ISSN 0735-1097. Vol. 58, No. 6; P.p.561-569.

Elsayed ES. (2004): Orientation guideline for patient undergoing cardiothoracic surgery. Thesis for degree of Msc., Medical Surgical Nursing, Faculty of Nursing, Ain Shams University; p.p. 60-83.

Eltahry SH. (2008): Assessment of Informational Needs of Patients with Congestive Heart Failure . Unpublished Master Degree. Faculty of Nursing - Suez Canal University (Medical Surgical Nursing).

Gerdes P. and Lorenz R. (2013): The Effect of an Outpatient Interdisciplinary. Heart Failure Education Program. The Journal for Nurse Practitioners- JNP, Vol .9, no7; P.p. 422- 427.

Goldberg L. (2010): Heart Failure in the clinic. American College of Physicians, Annals of Internal Medicine; Vol, 44 P.p. 1-16.

Henein M. (2010): Heart Failure in Clinical Practices. Springer-Verlag London; P.p. 255-276.

Jenner R., Strodl E. and Schweitzer R. (2009): Anger and Depression Predict Hospital Use among Chronic Heart Failure Patients, Australian Health Review, Vol .33, No 4; P.p. 541-548.

Jensen SH. (2015): Nursing health assessment a best practice approach. $2^{\text {nd }}$ edition. Wolters Kluwer. P.p., 413-437. 
Karen Y. (2009): The effect of shared medical visits on knowledge and self-care in patients with heart failure, Heart and Lung, (38): one; P.p. 25-33.

Karlsson R., Edner M. and Fvenmark C. (2011): professional education program for family members of patients with chronic heart failure. Patient Education and Counseling, vol, 85; P.p. 162-168.

Katz D., Friedman R. and Lucan S. (2015): Nutrition in clinical practice. $3^{\text {rd }}$ edition . Wolters Kluwer. P.p. 204-214.

Khan G. (2006): Approach practical: heart disease diagnosis and therapy. $3^{\text {rd }}$ ed., MCG Grow-hill Book company USA; p.p. 340-352.

Knopp A. (2009): Nurses Knowledge of Heart Failure Guidelines in A Western Montana Hospital. Master thesis, faculty of nursing, Montana State University; P.p.2035 .

Sherry K., Milfred L. and Sherly L. (2013): Clinical pharmacy services in heart failure, Pharmacotherapy, 33(5); P.p. 529-548 .

Sochalskl J., Jaarsma S., Krumholz, T. and Laramee H. (2009): What Works In Chronic Care Management: The Case Of Heart Failure .Health Affairs Journal, VOL. 28, NO 1; P.p. 321-329.

Lakdizaji S., Hassankhni H. and Agdam A. (2013): Effect of Educational Program on Quality of Life of Patients with Heart Failure: A Randomized Clinical Trial. Journal of Caring Sciences, VOL. 2, NO 1; P.p 11-18.

Lefteriotis CH. (2013): Depression in Heart Failure patients, Health science Journal, vol. 7, No 4; P.p. 349-355.

Mark H., Paris L. and Taylor L. (2014): A nurse-guided patient-centered heartcentered heart failure education program. Journal of Nursing Education and Practice, Vol. 4, No. 3; P.p. 49-57.

McGee S. (2012):-Evidence-based physical diagnosis .Philadelphia -Elsevier

McMurray, JJ., Adamopoulos S., Anker SD. And Bohm M. (2012): ESC Guidelines for the diagnosis and treatment of acute and chronic heart failure. Eur J Heart Fail, 14(8), 803-69.

Moore L., Dalley F. and Agur A. (2014): Clinically oriented anatomy, $7^{\text {th }}$ edition, Lippincott Williams and Wilkins.

Morgan J. and Naka Y. (2013): Surgical Treatment for Advanced Heart Failure. Springer New York Heidelberg Dordrecht London; P.p.1-24. 
Moser, DK., Dickson, Jaarsma T. and Lee C. (2012): Role of self-care in the patient with heart failure .Curr Cardiol Rep, 14(3), 265-75.

Pang P. (2011): Acute Heart Failure Syndromes Initial Management. Emerg Med Clin N Am 29; P.p. 675-688

Perez A., Jhund P. and Macdonald M. (2014): Fatigue as a Predictor of Outcome in Patients with Heart Failure. American College of Cardiology Foundation, Vol. 2, No. 2; P.p. 188- 197.

Pinkerman C., Sander P., Breeding JE., Brink D., Curtis R. and Hayes R. (2013): Heart Failure in Adults. Institute for Clinical Systems Improvement, $13^{\text {th }}$ Edition; P.p. 9-15

Polling G. (2013): Nurses rated highest in honesty and ethical standards. Retrieved from http//www.Gallup.com. Heart failure. British Columbia in Ministry of Health Services. Website: www.health.gov.bc.ca/msp

Reddy S., Bahl A. and Talwar K. (2010): How do we improve diagnosis \& management? Indian J Med Res. Vol .132, P.p. 549-560.

Richman H. (2010): Heart failure touching deep with music, emotional and physical; Http://www.sounfeetings.com/products/alternative-medicine / music - therapy / heart failure.

Thompson J. (2012): Cardiovascular problems. Philadelphia -Elsevier.

Thompson T. (2010): A Public Health Action Plan to Prevent Heart Disease and Stroke, American Heart Association; P.p.14-15.

Urden l., Stacy K. and Lough M. (2014): Critical care nursing ,diagnosis and management. $7^{\text {th }}$ edition, Elsevier Mosby. P.p. 366-374.

Walker B., Colledge N., Ralston S. and Penman I. (2014): Davidson's principles \& practice of medicine. $22^{\text {th }}$ edition, Churchill Livingstone Elsevier. P.p. 546-553.

Wang SH P (2011): Effectiveness of a self care program in improving symptoms distress and quality of life in congestive heart failure patients, Journal of Nursing Research, 19, (4): P.p. 257-265.

Weber R. and Kelley H. (2014): Health assessment in nursing. $5^{\text {th }}$ edition, Lippincott Williams and Wilkins. P.p. 416-446.

Williams I. and Hopper P. (2015): Understanding medical surgical nursing; $5^{\text {th }}$ edition .Davis Company ,Philadelphia. P.p. 522-544. 
Zile M., Gottdiener J. and Hetzel S. (2011): Prevalence and significance of alterations in cardiac structure and function in patients with failure and a preserved ejection fraction . Circulation; vol , 124; P.p. 2491-501.

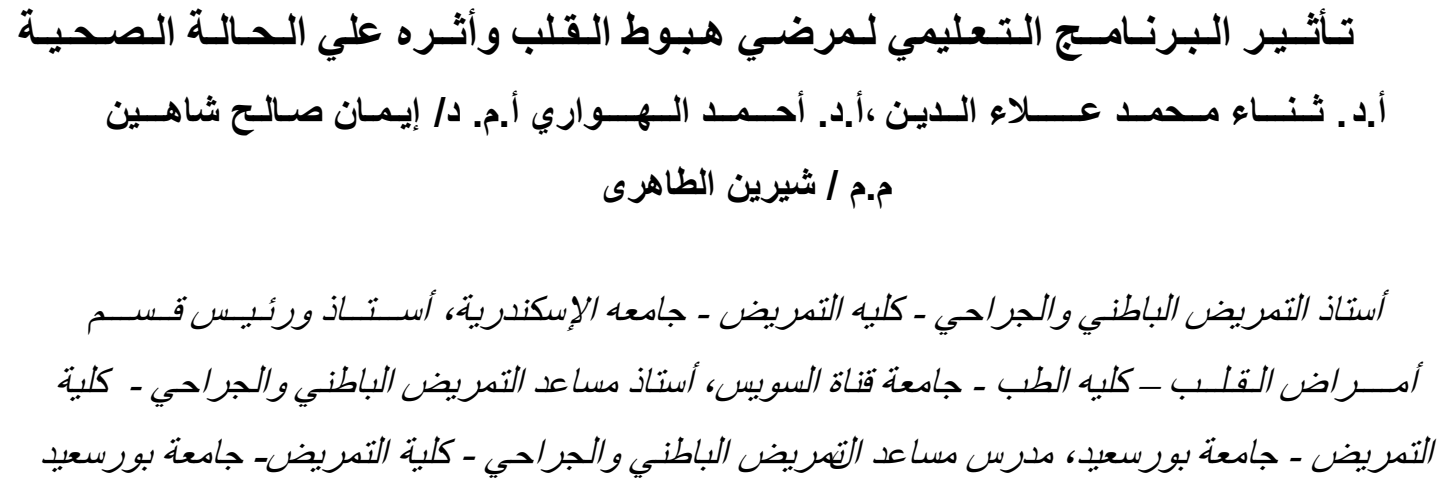

\section{الخلاصة}

الدر اسة الحالية دراسة شبة تجريبية هدفها تقييم تأثير البرنامج التعليمي علي معلومات مرضى هبوط القلب. وشملت عينة البحث (108) مريض بمستشفى بورسعيد العام و النصر و التضامن، وقد تم تجميع البيانات عن طريق استخدام استمارة استبيان للمرضى لتقييم ممارستهم لعرض هبوط القلب وتم تجميع الاستمار ات قبل البدء في البرنامج وبعد تنفيذ البرنامج مباشرة ثم بعد ثلاث شهور . وقد أسفرت نتائج البحث علي وجود تحسن و اضح في ممارسات المرضى بعد تتفيذ البرنامج مباثرة . بناء على نتائج الدر اسة أوصى بأن يتم عمل در اسة لتقبيم الحالة الوظيفية لمرضي هبوط القلب أثناء دخولهم المستشفى و أثناء خروجهم لمعرفة التغيير في حالتهم الوظيفية والذي من خلاله يتم تقييم البروتوكو لات. ـ تطبيق هذه الدر اسة علي نطاق عينة أكبر لتحقيق التعميم علي مدي أوسع في العلاج و الر عاية . 